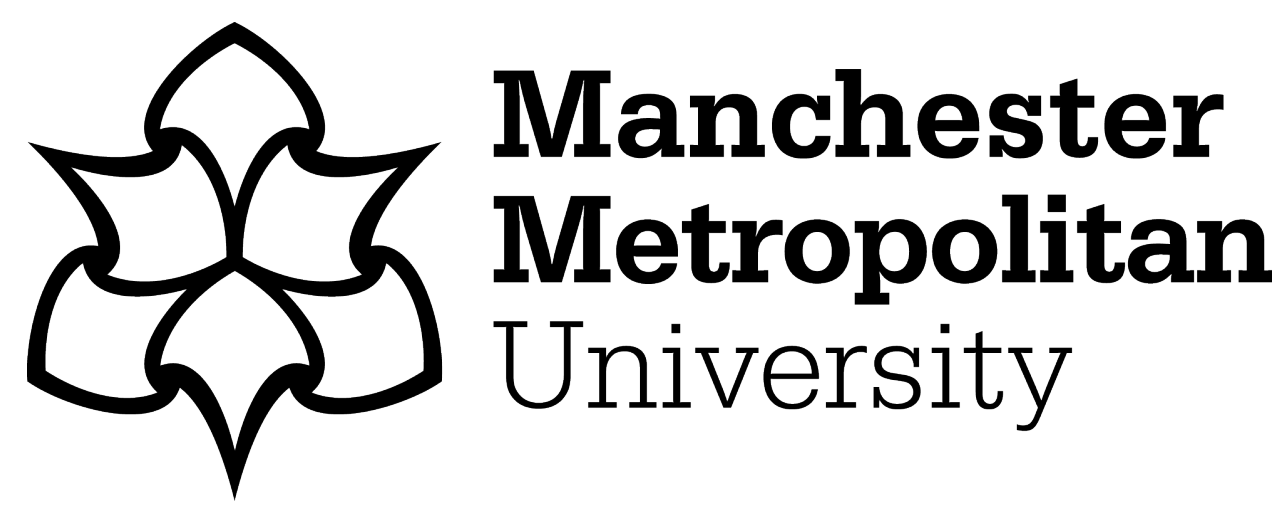

Paletta, A, Leal Filho, W, Balogun, AL, Foschi, E and Bonoli, A (2019) Barriers and challenges to plastics valorisation in the context of a circular economy: Case studies from Italy. Journal of Cleaner Production, 241. ISSN 0959-6526

Downloaded from: https://e-space.mmu.ac.uk/624961/

Version: Accepted Version

Publisher: Elsevier

DOI: https://doi.org/10.1016/j.jclepro.2019.118149

Please cite the published version 


\title{
Barriers and challenges to plastics valorisation in the context of a circular economy: case studies from Italy
}

\author{
Journal of Cleaner Production 24120 Dec 2019 \\ DOI https://www.sciencedirect.com/science/article/pii/S0959652619330197?via\%3Dihub
}

\author{
Angelo Paletta ${ }^{1}$, Walter Leal Filho ${ }^{2}$, Abdul-Lateef Balogun ${ }^{3}$, Eleonora Foschi ${ }^{4}$, Alessandra \\ Bonoli ${ }^{4}$ \\ ${ }^{1}$ Department of Management, University of Bologna, via Capo di Lucca, 34, Bologna, Italy, \\ angelo.paletta@unibo.it \\ ${ }^{2}$ European School of Sustainability Science and Research, Hamburg University of Applied \\ Sciences, Ulmenliet 20, D-21033 Hamburg, Germany \& Department of Natural Sciences, \\ Manchester Metropolitan University, Chester Street, Manchester M1 5GD, UK- \\ walter.leal2@haw-hamburg.de \\ ${ }^{3}$ Geospatial Analysis and Modelling Research Group (GAMR), Dept. of Civil and \\ Environmental Engineering, 32610 Seri Iskander, Malaysia - geospatial63@gmail.com \\ ${ }^{4}$ Department of Civil, Chemical, Environmental and Materials Engineering, University of \\ Bologna, via Terracini 28, 40131 Bologna, Italy - eleonora.foschi3@unibo.it , \\ alessandra.bonoli@unibo.it
}

Highlights:

- Plastics pose a major pressure to the natural and human environment

- The use of non-virgin plastic materials should be reduced

- Integrated plastic value chain leads to environmental and economic gains

- Innovative solutions are needed to better integrate plastics as part of the circular economy

\begin{abstract}
In 2017, over 320 million tons of polymers, excluding fibers, were manufactured across the globe. The excessive amounts of plastics produced today pose a threat to both man and nature. Urgent approaches towards reducing plastic consumption and increasing its recyclability are needed. This paper discusses the matter of accelerating the circularity of plastic-based material systems. It investigates a sample of plastics-converting companies in Emilia Romagna region (Italy), which stand out for radical innovations in business models, with the aim to catalyse changes in current manufacturing practices. The findings provide empirical support for a positive relationship between business strategies and the use of non-virgin plastic materials. The innovative value of this paper relies on the fact that it elaborates on the vision established within the European Strategy for Plastics in a Circular Economy that sets ambitious targets about achieving high plastic recycling targets by 2025. Legislative, economic, technological
\end{abstract}


and social barriers can only be tackled by radically revising the current philosophy of designing, producing, distributing and consuming plastic as part of goods and services. A systemic thinking perspective is an essential building block in this context: moving from a micro to a meso-scale analysis can represent a useful means supporting the creation of viable management approaches towards achieving environmental and economic gains, especially in European plastic conversion industry, where SMEs are the majority (about 50000). Thanks to its analysis and scope, this paper provides useful insights to the plastic industry: it shows that this substantial improvements in this sector will require innovative solutions and major efforts by key decision makers, producers, recyclers, manufacturer, retailers as well as consumers.

Keywords: plastic - consumption - production - contamination - industry

\section{Introduction: The plastic pollution problem}

Plastics are highly durable non-biodegradable materials made from petroleum products (Landon-Lane., 2018; Eagle, Hamann, and Low., 2016), with a lifespan ranging from hundreds to thousands of years (Wang et al., 2016). Their versatile nature and durability make them indispensable, prompting its high demand and use globally. Over 300 million tons of plastics are produced annually (Karlsson et al., 2018; Napper et al., 2015; Jambeck et al., 2015). This is a significant increase from the 1.7 million tons produced in 1950 (Kwon et al., 2018; PlasticsEurope, 2015). The widespread use of plastic materials causes widespread pollution affecting different components of the eco-system (Leal Filho et al., 2019a; Eagle; Hamann, and Low, 2016).

Understanding the scale of the problem is crucial to plan the best framework of interventions (Leal Filho et al, 2019b). Approximately $80 \%$ of plastic wastes originate from land sources (Landon-Lane., 2018; Cole et al., 2011), which is largely due to the incorrect disposal and mismanagement of waste on land, causing plastic pollution (Xanthos and Walker, 2017; Villarrubia-Gomez, Cornell, and Fabres, 2017). Illegal dumping, run-off, littering, and natural disasters are common pollutant sources (Carpenter and Wolverton, 2017; Dris et al., 2016). Proximity of plastic industries to rivers, oceans and other water bodies has been identified as a major enabler for plastic induced environmental pollution. Wastes from production plants in various sites leach into the environment, transported through rainfall, rivers, oceans, wind etc. (Mani et al., 2015; Eriksen et al., 2013). Human activities on populated islands are also sources of plastic pollution (Monteiro et al., 2018; Miller et al., 2017), together with prevailing consumption model of several plastic items, which produce significant quantity of waste. For instance, the large-scale consumption of plastic bags (PB) in developed and developing countries is a source of PB pollution. Ramaswamy and Sharma (2011) noted that a large amount of PB is utilised worldwide and an equally large quantity is disposed of, often illegally. These have severe consequences, ranging from environmental, to social and economic impacts (Debrot et al., 2013). Conversely, ocean activities such as shipping, and fisheries equally produce plastic debris which are transported rover considerable distances to islands by wind and ocean currents. Beaches have been identified as repositories for millions of plastic wastes (Lavers and Bond., 2017). 
Globally, the problem of plastic pollution has become a major source of concern for governments, investors, and other stakeholders (Seltenrich, 2015). Some claim this is due to poor design, even though Eastwood and Haapala (2015) designed a unit process model-based methodology to assist product sustainability assessment during design for manufacturing. In recent times, plastic pollution has emerged as one of the most serious threats to ocean ecosystems (Chiba et al., 2018) and terrestrial ecosystems ( $\mathrm{Ng}$ et al., 2018), although current understanding of the extent of the ecological impact of plastic pollution on the terrestrial environment is limited. Unfortunately, harmonised research and policies to reduce pollution from diverse sources are lacking (Xanthos and Walker, 2017). Although the impacts of plastics are well documented in the literature, along the measures which may be deployed to address them, studies and policies hinged on mitigating plastic toxicity in the environment are inadequate or limited (Pettipas, Bernier, and Walker, 2016). To properly comprehend the plastic pollution problem and offer workable solutions, it is essential to undertake a holistic analysis of the value chain of plastics. At present, such studies are at the inventory level (Monteiro et al., 2018). Therefore, the objective of this paper is to address this need by performing empirical analyses of plastics circular economy, utilizing data from different companies with unique business models.

The concept of circular economy has become increasingly widespread in academics, industry, among political decision-makers and society (Kirchherr et al. 2017). Rossi, Germania and Zamagnibc (2015) undertook a review of eco-design methods and tools, identifying barriers and strategies for effective implementation of eco-design in industrial companies, which may facilitate the pursuit of a circular economy. If eco-design is imperative, mature collection scheme, as well as recycling capacity are also essential (Al-Salem et al., 2009). Last but not least, the absorption of recycles into the market is indispensable to close the loop and fulfil the circularity. The involvement of all stakeholders working in the plastics value chain contributes to catalyse the transition in a more effective way.

But there is some ambiguity on the use of the term and its significance with respect to plastics value chains. Geissdoerfer et al. (2017) claim that the most prominent circular economy definition has been provided by the Ellen MacArthur Foundation (2013), which reads: "(CE) is an industrial system that is restorative or regenerative by intention and design. It replaces the 'end-of-life' concept with re-storing, shifts towards the use of renewable energy, eliminates the use of toxic chemicals, which impede reuse, and aims for the elimination of waste through the superior design of materials, products, systems, and, within this, business models". This definition makes it clear that the operating model of circular economic systems must not be confused with a new waste management system. The circular approach implies a much more forward-looking business model and economic behaviour (investment, production and consumption), where recycling is only one of the possibilities (Raworth., 2017). We need to rethink the whole life cycle of products and materials, from their design to technologies and production systems up to distribution, consumption, collection, recycling, and final disposal methods. Also, health issues should be taken into account (Leal Filho 2019b). 
Under such circumstances, the circular economy implies an anticipatory approach based on which the generation of refuses and waste is not a problem to be dealt with at the end of the production process or after the product has completed its useful life, but must be kept in mind from the beginning, planning all the possible alternatives to reduce the environmental footprint of the product throughout the life cycle (Hall et al., 2018; Lieder and Rashid 2016, Ghisellini et al., 2016). This concept appears to be important for the value chain of plastics where different applications and formulations create additional complications.

In January 2018, the European (EU) Commission highlighted the importance of the problem with its European Strategy for Plastics in a Circular Economy and outlined the challenges, strategies and opportunities for a more sustainable and safer consumption and production patterns of plastics (European Commission., 2018a). Even if some circular models have been applied for years, more effort is needed to boost plastic value chain towards closing loop system. In fact, while EU recycling technologies and knowledge are consolidated and among the most technically advanced in the world, the quality of recycles, as well as the acceptance for the use of secondary materials, should receive more attention. The waste hierarchy (European Parliament and the council of the European Union, 2008) is also stimulating prevention, as prioritized to recycling. Nevertheless, there are various challenges in the production and waste management system to make the plastic industry more sustainable. Many obstacles continue to exist which prevent recycling activities from realizing an effective circular economy model for plastics. Technical-technological, legislative, economic and sociocultural barriers are taken into consideration to radically revise the current philosophy of designing, producing, distributing and consuming goods and services.

This paper introduces the discussion from the problem of accelerating the circularity of plasticbased material systems with the vision of carbon-neutral material system in 2050. We investigate a pool of plastic converting companies that stand out for radical innovations in business models, with the aim to analyse changes in current manufacturing practices, including the design for reduce, re-use and recycling as key strategy to ensure the use of recycled plastics as raw materials into new products and goods. The investigation focuses on companies located in the Emilia Romagna region (one of the more productive Italian regions in the packaging field) classified as category C22 (referring to rubber and plastic products manufacturing) from the Statistical classification of economic activities in the EU Community (NACE). The study comprises a framework of surveys, administrated in two different phases in the years 2012 and 2018 .

The findings provide empirical support for a positive relationship between business strategies and the use of non-virgin plastics materials, referred to as both secondary plastics and industrial debris. The potential impact of a circular economy for plastic is huge, but this is not the result of companies that operate outside an environmental-oriented supply chain cooperation. Engagement with key networks and stakeholders in the relevant fields (e.g. plastics value chain, digitalisation, climate action, etc.) is the driver to reduce the adverse impacts of the generated waste on the environment and human health, and the content of harmful substances included 
in plastics. The practical implications of the paper are relevant to promote best practices dissemination and consequently, to encourage a more collaborative and integrated value chain.

\section{Plastics value chain}

Due to a wide variety of properties, including versatility and adaptability, plastics are used in various applications and in a multitude of products. Plastics production and consumption have seen a rapid growth, surpassing most other man-made materials (Geyer et al., 2017). The EU plastics industry ranks $7^{\text {th }}$ in industrial value-added contribution covering a total amount of 60000 companies, from manufacturers $(3,77 \%)$ to converters $(94,34 \%)$ to recyclers $(1,89 \%)$ (https://www.plasticsconverters.eu/). Plastic materials, thermoplastics and polyurethanes, and other plastics such as thermosets, adhesives, coatings, and sealants (excluding fibres) produced in 2016 in EU28 ( $+\mathrm{NO}, \mathrm{CH}$ ) was 60 million tonnes, two million tonnes more than in 2015. Considering only plastics raw materials manufacturers and converters, it had registered a trade balance of close to 15 billion euros in 2016 (PlasticsEurope, 2017).

The plastic value chain, whose simplified version is shown in Figure 1, involves different players: plastic raw materials producers generally apply thermal and catalytic cracking to valorize low-value hydrocarbons into higher value products (Sadrameli, 2016). Depending on the requirements necessary to produce specific plastic products, compounders add chemical substances to enhance polymer properties such as workability, flexibility and strength. Plastic converters, mainly in packaging, building and construction (B\&C), automotive, electricalelectronic (EE) applications, assembly plastics resins and other materials to produce semifinished and finished products.

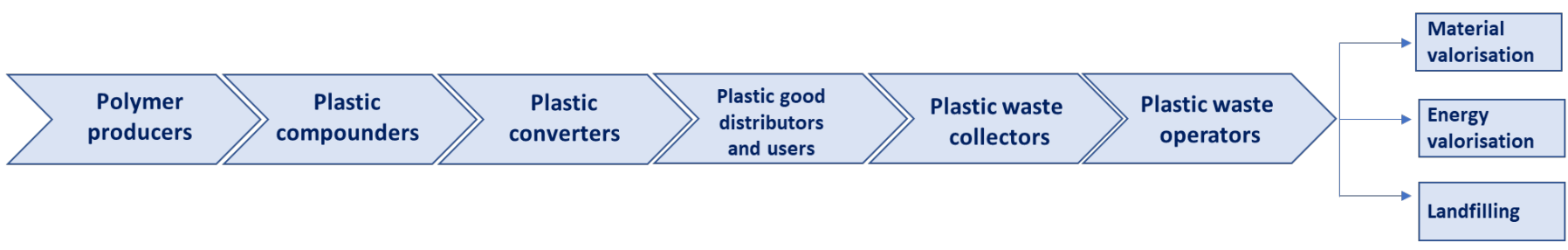

Figure 1 - Plastic value chain, a simplified version

The final part of the plastic value chain, next to distribution and consumption phases, deals with the end-of-life (EoL) scenario, represented by collection, sorting, recycling and disposal of plastic waste deriving from community, users and consumers, that produce a high and diversified volume of post-consumer plastic waste (Brems et al., 2012). Pre-consumer plastic waste, concerning industrial waste, are also taken into consideration. The high quality of industrial waste facilitates its own valorization by recycling process. In addition to material valorization, plastic waste can be incinerated (with energy recovery) or landfilled.

\subsection{Plastic materials production}

Primary plastics production refines crude oil and produces monomers that are chemically bonded into polymers. The different combinations of monomers and their blending with 
oxygen, chlorine, fluorine and nitrogen generates different types of plastics (Harper., 2005, Rosato et al., 2000). Monomer production is the domain of big companies, mainly oil and chemical, which may also carry out polymerisation and blending activities. Polymers and plastics, especially polyethylene (PE), polypropylene (PP), polyvinyl chloride (PVC), polyethylene terephthalate (PET), polystyrene (PS) and polycarbonate (PC) comprise about $80 \%$ of the industry's output worldwide (Singh and Sharma, 2008).

In 2016, Europe produced 60mt of plastic, corresponding to $19 \%$ of world production. Asia is in first place accounting for about $100 \mathrm{Mt}$ of plastics consumed in the same year (Figure 2).

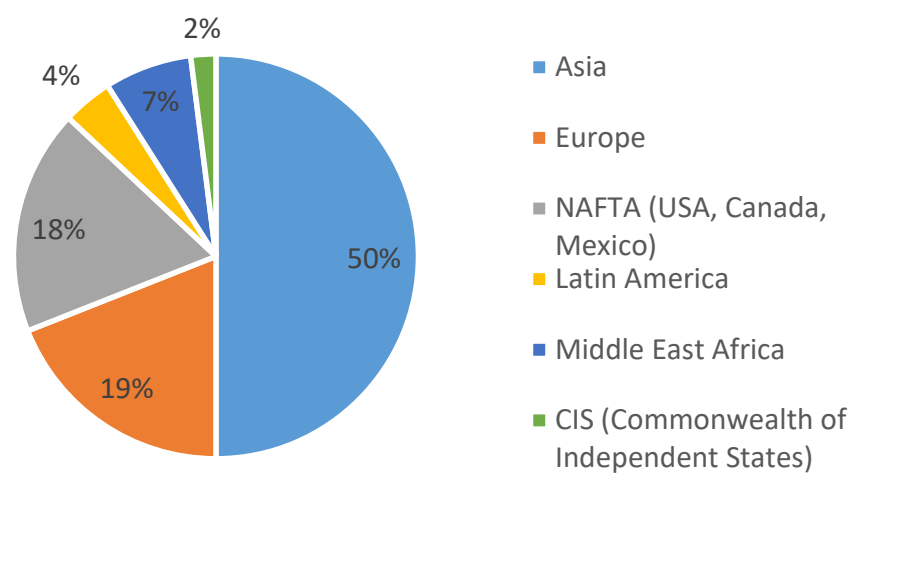

Figure 2 - Word plastic production - Source: PlasticsEurope, Plastics - the Facts 2017(2017)

\subsection{Plastic products manufacturing}

According to the annual report published by PlasticsEurope (PlasticsEurope, 2017), the EU plastic converter demand was 49,9 Mt in 2016. The most profitable sectors for plastics conversion, as shown in Figure 3, are packaging (39,9\%) and B\&C (19,7\%). Then, considering that $12 \%$ of materials in an average car today are plastics (Muñoz et al., 2006; Ragosta et al., 2000 ), 8,9 Mt of plastic are used in the automotive sectors, covering the $10 \%$ of total demand, followed by EE (6,2\%), household, leisure and sports $(4,2 \%)$, agriculture $(3,3 \%)$ and other sectors. 


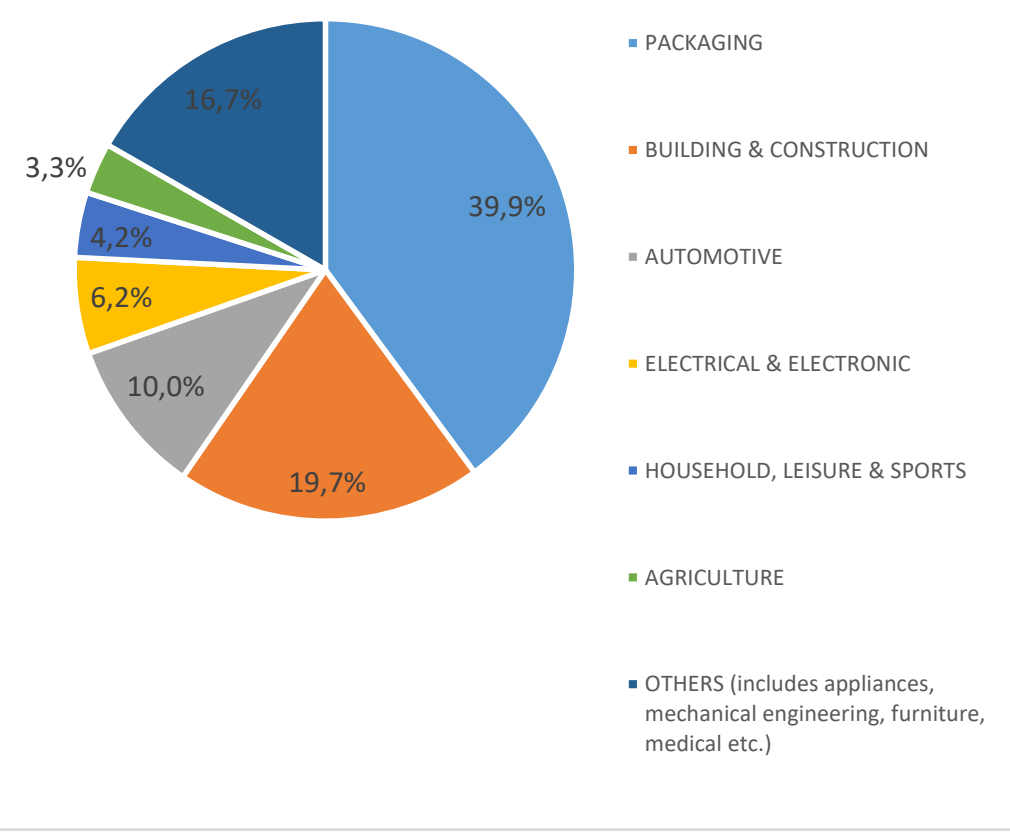

Figure 3 - Distribution of European (EU28+NO/CH) plastics converter demand, by segment in 2016 - Source: PlasticsEurope, Plastics - the Facts 2017 (2017)

Omitting data on fibres and additives production (these are not readily available at European level), Figure 4 highlights the details of the resins type in Europe: PP and polyethylene lowdensity (PE-LD) prevails than polyethylene high-density (PE-HD), PVC, polyurethane (PUR), PET, and PS or expanded polystyrene (PS-E).

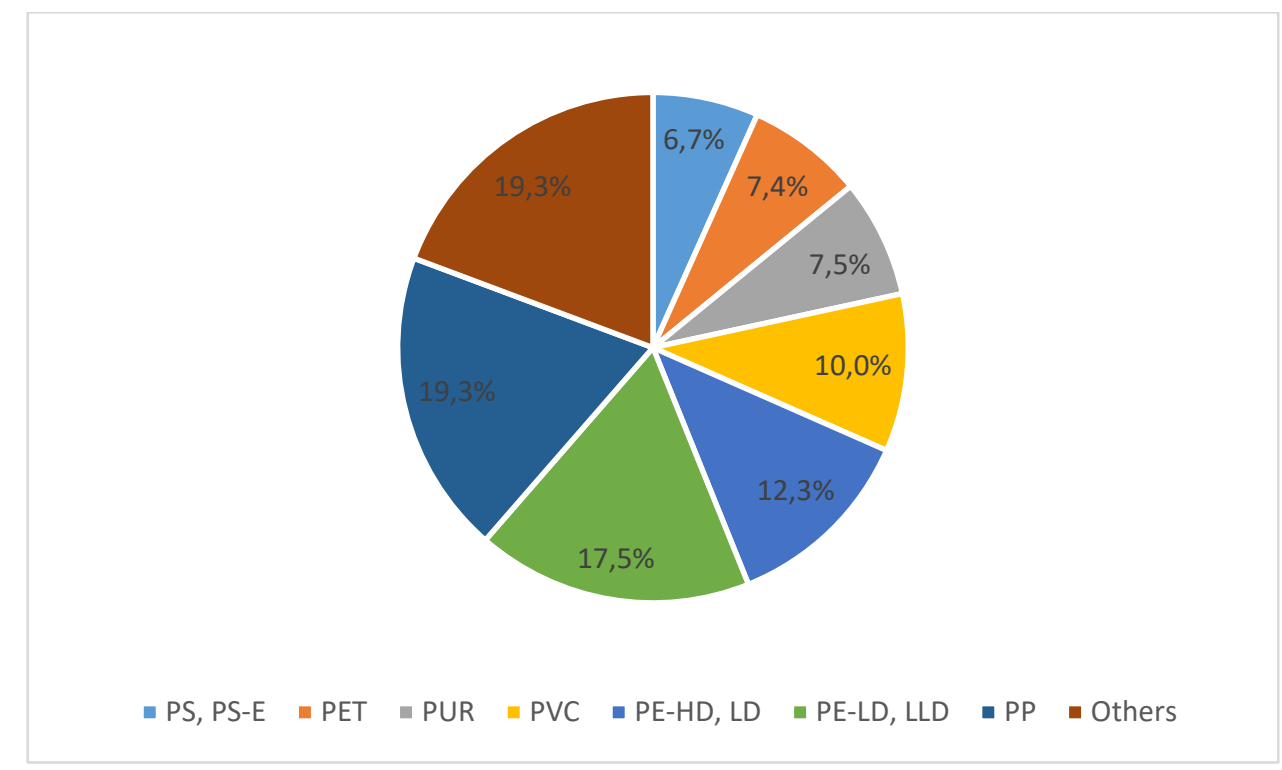

Figure 4 - European plastics converter demand, by polymer types in 2016.

Source: PlasticsEurope, Plastics - the Facts 2017 (2017) 
Plastic waste generation is strongly influenced by primary plastic production and use. As shown in Figure 5, the breakdown of the plastic resins content in the six main waste streams reflect the polymers demand in the main applications.

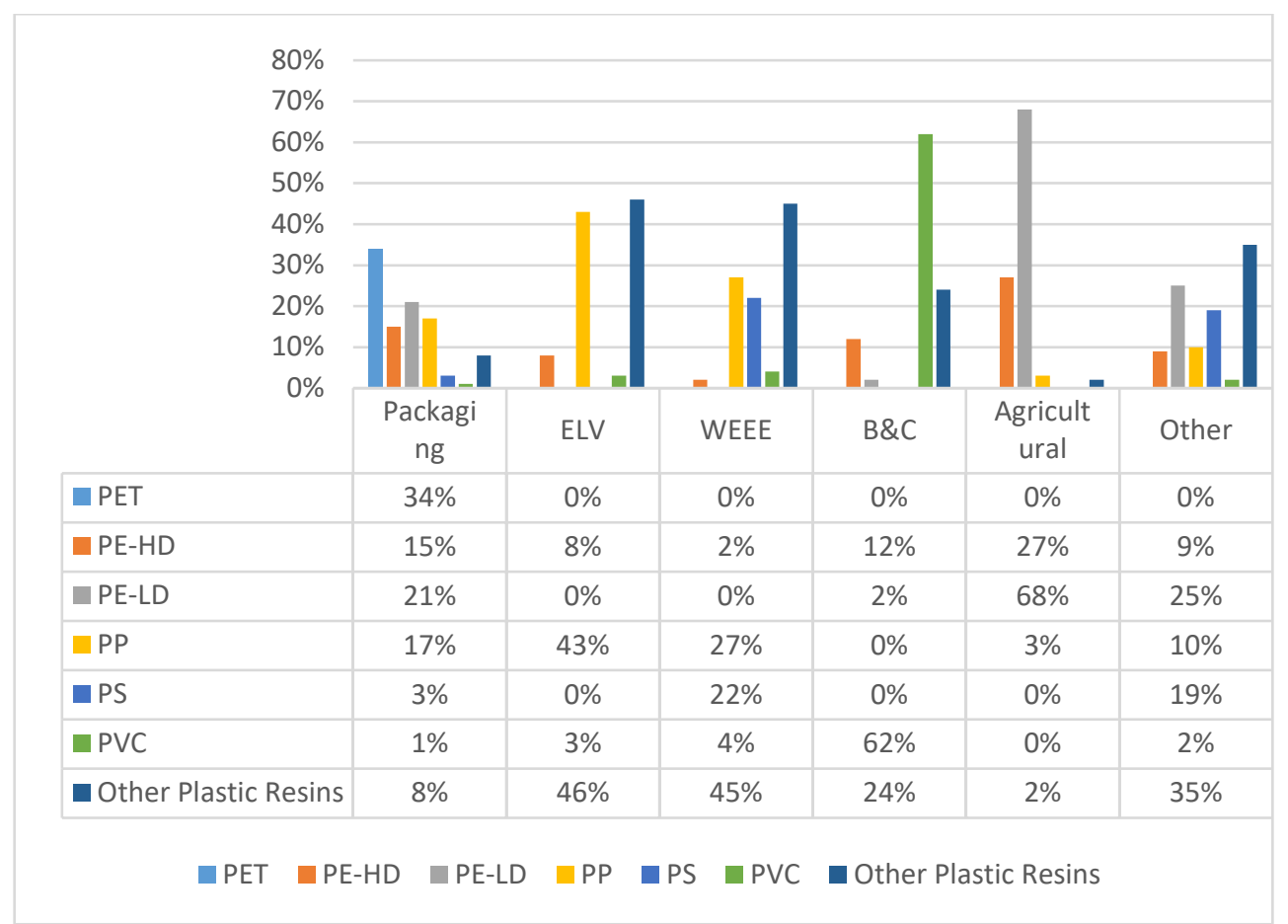

Figure 5 - Breakdown of the plastic resins content in the six main waste streams in 2014 Source: Deloitte, Increased EU Plastics Recycling Targets: Environmental, Economic and Social Impact Assessment (2015)

$\mathrm{PP}$ is a characteristic polymer in automotive components, but it is also used for food packaging, sweet and snack wrappers, microwave, pipes, and bank notes. PE-LD is the favoured material for plastic bags and packaging film while PE-HD is adopted for toys and cleaning bottle manufacturing (Lopez et al., 2004; Ozdemir et al., 2004; Yildirim et al., 2018). The highest demand for PVC comes from B\&C sector (Sadat et al., 2011). PVC is a polymer largely used for many building components from windows and doors profiles to pipes, cables and floor coverings. The packaging sector is the main industrial customers for PET. All bottles containing liquid are made by PET (Welle, 2011; Nascimento et al., 2010) while caps use PEHD. Polyurethane (PUR), a common thermoset polymer, is used for daily household and nonreturnable goods like pillows, mattresses, fridges, eyeglasses etc.

Recent years have shown an increasing demand for environmentally friendly polymers as well (Li et al., 2001). Environmentally friendly polymers have been studied for years, generating "biodegradable plastics" or "bio-based plastics". Biodegradable plastics can be degraded by microorganisms able to adopt them as a substrate for their metabolism. Therefore, complex polymeric chain can be decomposed into water and carbon dioxide or methane, respectively with aerobic or anaerobic conditions. Biodegradable plastics can be synthetized either from 
biogenic or fossil feedstocks. Bio-based plastics, different from biodegradable ones, can be only synthetized from biogenic sources, even if the structure is identical to correspondent synthetic polymeric. However, even if the source is biogenic, they are not necessarily biodegradable (Orhan et al., 2004). Biopolymers include polysaccharides such as cellulose and starch, carbohydrate polymers produced by bacteria and fungi, protein polymers derived from soy protein and animal protein-based polymers such as wool, silk, gelatine, and collagen (Avérous, 2013). Bioplastics can be either biodegradable or non-biodegradable (Di Gregorio, 2009; Harding et al., 2017). Biodegradable plastics can also be partially petroleum-based or can contain a mixture of petroleum-based polymers and biopolymers. Polylactic acid (PLA), polyvinyl alcohol (PVA), and polybutylenes succinate (PBS) are examples of polymers that have synthetic origin but are also biodegradable. According to the market analysis compiled by European Bioplastics (2018), global bioplastics production capacity was about 2.06 tonnes in 2017. Bioplastics are used in an increasing number of markets, from packaging catering products, consumer electronics, automotive, agriculture/horticulture and toys to textiles and several other segments (Zheng et al., 2005). Packaging remains the largest field of application for bioplastics at almost $60 \%$ (European bioplastics, 2018). However, since biopolymers are mostly biodegradable, and some of them also compostable, their application makes sense when a reasonable time frame of degradation is considered (European Commission, 2018b). In addition, they have much less stability and durability than petroleum-based polymers. They generally present poor mechanical properties regarding processability and end-use application, since the fragility and brittleness exhibited during thermoforming can limit their potential for application (Vieira et al., 2011).

\subsection{Plastic waste management}

Depending on their functionality, performance and properties, different life cycle of plastic products can be considered. Based on these criteria, plastic goods are classified as durable or non-durable. The durable goods cover a useful life of three years or more and generally refer to appliances, furniture, consumer electronics, automobiles, and insulation materials for construction sector. Products with a useful life of less than three years are generally referred to as non-durables. Depending on the chemical composition, involving a specific molecular structure, and additives included, a broad variety of applications can be satisfied. Common applications include packaging, trash bags, cups, eating utensils, sporting and recreational equipment, toys, medical devices, and disposable diapers (Fishman et al., 2000). Ironically, plastics' durability and resistance, which is responsible for the proliferation of plastic materials in manufacturing, also cause problems in terms of plastics waste management.

Plastic waste is among the most critical waste categories in the world, owing to its long-term degradation (Rigamonti et al., 2014). It follows that the volume of collected waste cannot match, in a single year, the volume of production or consumption (OECD, 2018). As shown in Fig 6, 27,1 Mt of plastic post-consumer waste was collected, through official schemes, in 2016 in EU28 $(+\mathrm{NO} / \mathrm{CH})$. In terms of sustainable waste processes, recycling is a sustainable alternative waste disposal strategy other than landfill and incineration (Lea., 1996). Recycling of waste plastics emerged during the early 1990s. Since 1990, the global rate of recycling has 
increased by approximately $0,7 \%$ per annum to the current rate of $20 \%$ (Geyer, Jambeck and Law, 2017). Due to the rapid depletion of natural resources, many organizations have realized that recycling of used products can be a building block to achieve competitive advantage (Kaya et al., 2011), however, it is still the second option in the actual European waste management system. In fact, only $31,1 \%$ of plastics is sent for recycling, the remaining are landfilled $(27,3 \%)$ and incinerated for energy recovery $(41,6 \%)$ (PlasticsEurope, 2017). Because of its short 'in use' lifetime, high use and consumption, packaging is the largest contributor to plastic waste generation. 16,7 $\mathrm{Mt}$ of plastic post-consumer packaging waste was generated in EU28 $(+\mathrm{NO} / \mathrm{CH})$ in 2016 . The other sectors produce a huge number of plastic products, but the long lifespan causes yearly plastic waste production to be smaller. In the construction sector, Plastic products can last between 30 and 40 years before being disposed of. In the automotive sector, the average life span of vehicles is around 13.5 years while the EE devices have a service life of 3-12 years. However, packaging waste, if efficiently collected and separated, turns out to be the most recyclable waste, thanks also to the kind of high-quality polymers, products "ecodesign" and recycling process optimisation that is adopted. Figure 6 shows that $70 \%$ (equal to $16,7 \mathrm{Mt}$ ) of European plastics packaging is recovered, $40,9 \%$ is recycled, $38,8 \%$ is energetically valorised, and only $20,3 \%$ is landfilled.

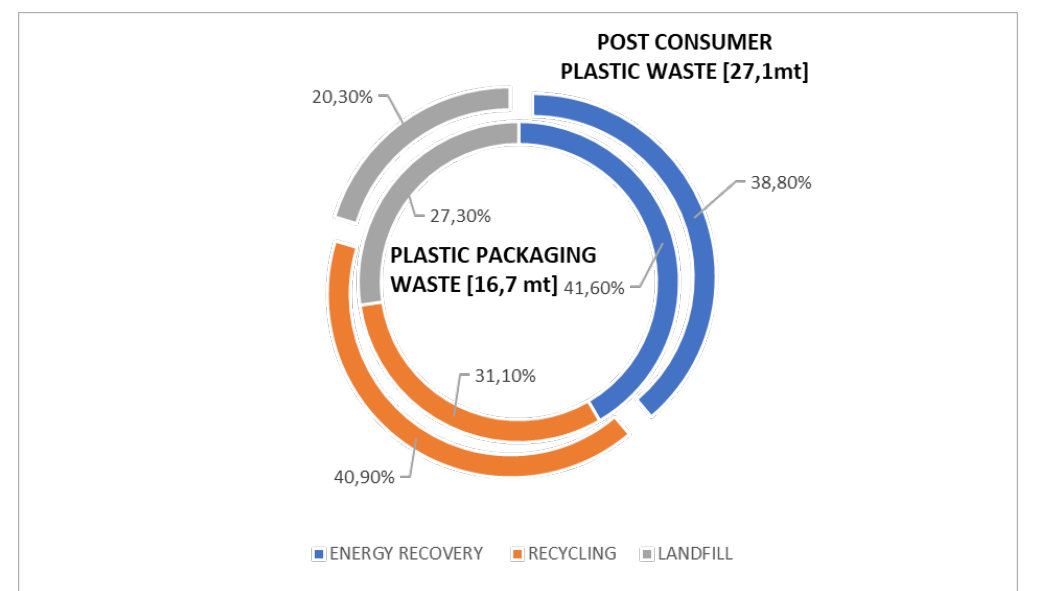

Figure 6 - Plastic post-consumer waste management - Source: PlasticsEurope, Plastics - the Facts 2017 (2017)

\section{Challenges for more sustainable production and consumption patterns in the plastics industry}

To analyse how the implications catalysed by the new EU purposes on plastics recycling and recyclability have been influencing the behaviour of plastic industry and the related business models, a study has been carried out using a sample of manufacturing companies working on plastics conversion in the Emilia Romagna region (Italy).

\subsection{Objectives of the study}

The study is focused on the manufacturing plastic value chain and is oriented to assess:

- The current use of polymers, materials and technology and unmet needs 
- The changing role of the materials' suppliers during the period 2012 - 2018

- Top industry issues and challenges

in order to overcome the perceived obstacles and disseminate best practices on plastic circularity. This paper offers a welcome contribution to the literature, since it outlines some means via which plastic valorisation can take place.

\subsection{Methods and tools}

The study was undertaken by Alma Mater Studiorum, University of Bologna (UNIBO) and supported by the Consortium for innovation and technology transfer of Emilia-Romagna region (ERVET). The investigation includes companies located in the Emilia Romagna region (one of the most productive Italian regions in the packaging field) classified as category C22 (referring to rubber and plastic products manufacturing) from the Statistical classification of economic activities in the European Community $\left(\mathrm{NACE}^{1}\right)$. The study involved 364 companies and consists of surveys, administrated in two phases, in the years 2012 and 2018. The aim is to compare the business model and supply chain before and after the European commitment on plastics. Of the 364 companies categorized by C22 NACE code, 41 (12\%) took part in the study performed in 2012. This sample has been used to replicate the investigation in the year 2018 . The second survey has been submitted to the same companies that had completed the survey in 2012. Owing to modifications on business segments of few companies, the final number of conversion companies under the comparative investigation amounted to 35 . In addition to a quantitative analysis, a qualitative investigation has been performed to explore barriers and challenges for plastics circularity, where barriers have been categorised as follows:

- Technical and Technological

- Legislative

- Economic

- Socio-cultural

The investigation is carried on from two perspectives:

- Micro-scale perspective, from the converters point of view, analysing barriers towards non-virgin plastic products manufacturing

- Meso-scale perspective, embracing a wider analysis involving the overall stakeholders working in the plastic value chain

According to the responses, companies with unmodified supply chains, have been defined as unreactive compared to those which have switched the procurement of plastics, from virgin to recycled ones. The so-called proactive sample has been analysed in detail to identify best practices in non-virgin plastics supply chain. The so-called unreactive sample has allowed a qualitative study on barriers and complications which limit the reduction of fossil-based stock

\footnotetext{
${ }^{1}$ NACE (Nomenclature of Economic Activities) is the European statistical classification of economic activities.
} 
supplies. The obstacles are then analysed in a wider context, moving the study from micro to meso level (Figure 7).

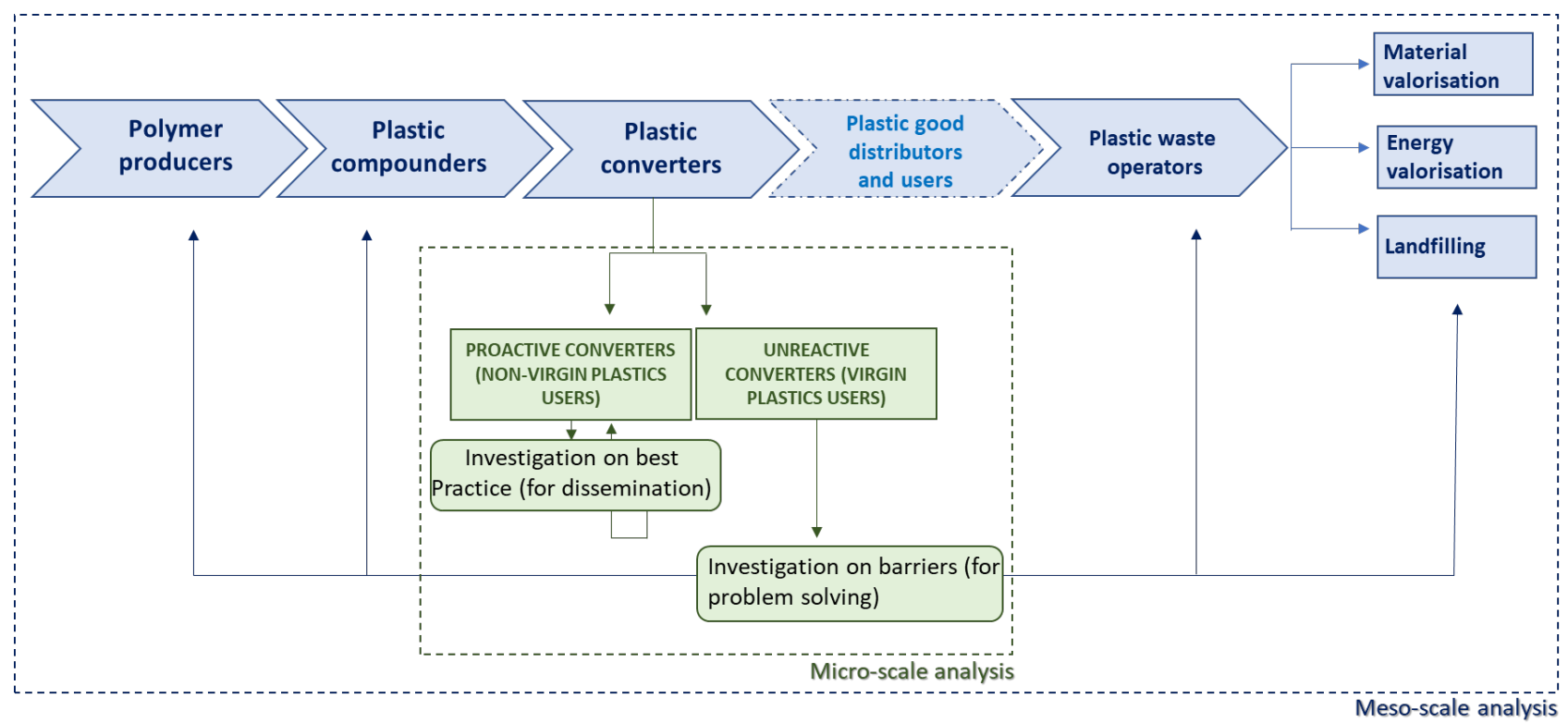

Figure 7 - Study method: Investigation from micro and meso scale perspective, in a holistic system

Integrating the study in a holistic system, and looking for solutions along all the value chain, allows for obstacles that interrupt the continuous material flow for plastics circularity optimization to be identified, and subsequently overcome. At the same time, disseminating best practice helps to accelerate the transition towards non virgin-plastics consumption, thus pursuing the decoupling between virgin materials extraction and economic growth.

\subsection{Results and discussion}

According to product-specific requirements, the investigated companies manufacture plastic products through injection, extrusion, blow moulding, welding and printing of different polymers. Respondents use general polymers (especially PP, PE, PS, PVC), engineering polymers (such as Nylon, PA, PET etc.) and elastomers. The use of thermoset polymers (PUR, Urea, Silicon etc.) and specialty engineering resins, is rather low; bio-based polymers are only experimented with in some processes. The market primarily served by these companies are packaging, automotive, B\&C and, less considerably, EE and medical.

The investigation deals with the use of non-virgin plastics, both as scraps and secondary resources. Plastic debris are usually reused in the same or in similar process, after the primary processes of shredding and mixing of virgin polymers and additives. While scraps can be internally recycled, plastics from waste are subject to external processing treatments, including sorting, shredding and recycling. Recycling plastics involves processes such as washing, melting, extrusion and granulation (PWMI, 2016; Goodship., 2007). Waste coming from postconsumer activity are mainly managed by the National Plastic Consortium (Corepla). However, 
Corepla, as part of the National Packaging Consortium (Conai), manages only packaging waste; the rest of plastic waste is not served by a specific consortium and it's usually incinerated. Post-industrial waste handling is not monitored by a waste management scheme and is adjusted by a free and competitive market. However, the recycling rate of post-industrial waste is higher than the post-consumer one where inhomogeneity, un-readiness and contamination underperform the end-of-life treatment.

Figure 8 shows the current use of plastics in the study region. Data on the use of non-virgin plastics indicates that the situation has not changed much during the last six years (2018 in comparison with 2012). The number of companies that use non-virgin plastics remains almost the same in 2012 and 2018. A trend inversion has been registered for two companies.

The investigation reveals that most of pro-active companies (referring to companies that use non-virgin plastics) has a consolidated experience in valorising plastic debris, reinserting them in the same manufacturing process after a milling process. The additional use of non-virgin plastics is seen in a few companies.

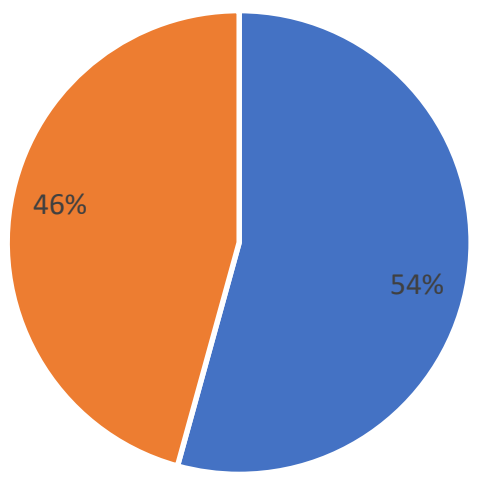

- Use of Non-virgin plastics in manufaturing process

- No use of Non-virgin plastics in manufaturing process

Figure 8 - Use of virgin and non-virgin plastic materials in plastic industry (C22 NACE code) in Emilia Romagna region

The preference for pre-industrial and industrial debris over secondary plastics is mainly due to:

- Easy collection because of the fewer points of generation

- More predictable composition

- Clear composition of a single type of polymer

- Lower content of impurities

- Greater compatibility with the following manufacturing processes

- Lower price

- Easy availability in the regional market 
The only company dealing with post-consumer waste has overcome general critical issues by implementing a virtuous business model based on a joint-venture with a recycling firm so as to achieve high standards for food-compliant applications.

Even if the number of pro-active and un-reactive companies remains almost the same, the amount of recycled plastics is generally increased in the proactive companies, especially in those having the highest use of alternative plastics, reaching over $50 \%$ of green supply (Figure 9).

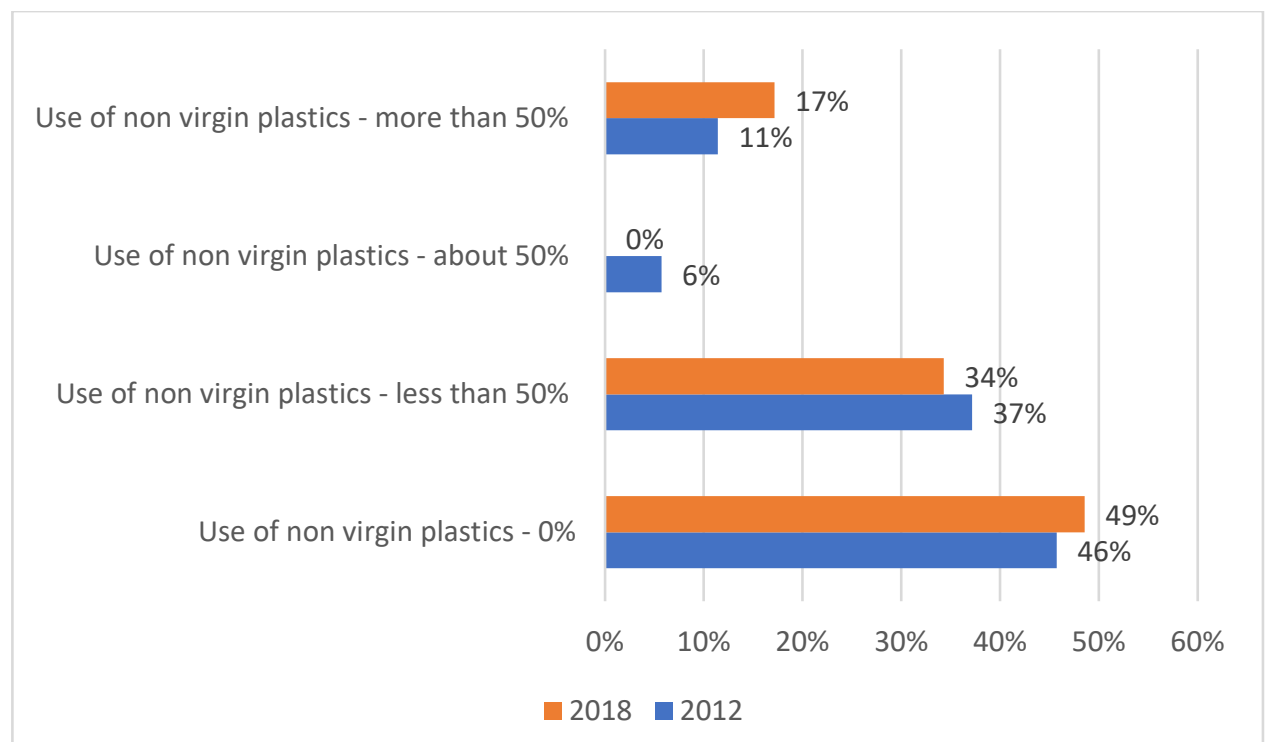

Figure 9 - Percentage of non-virgin plastic use in plastic industry (C22 NACE code) in Emilia Romagna region

It follows that while pro-active companies have picked up the positive impact of rethinking supply towards more sustainable resources.. This study has also examined the framework of barriers which are limiting the transition towards a more sustainable supply chain.

\subsubsection{Barriers to plastic circularity: Microscale analysis}

The qualitative analysis has been carried out to identify constraints and barriers limiting the adoption of a sustainable supply chain in the regional plastic economy. As illustrated in Figure 10 , the predominant barriers are the technological one in both years. Legislative barriers are subject to a reduction in 2018, even if legislation remains an obstacle for specific sectors, such as $\mathrm{EE}, \mathrm{B} \& \mathrm{C}$ and the medical one. 


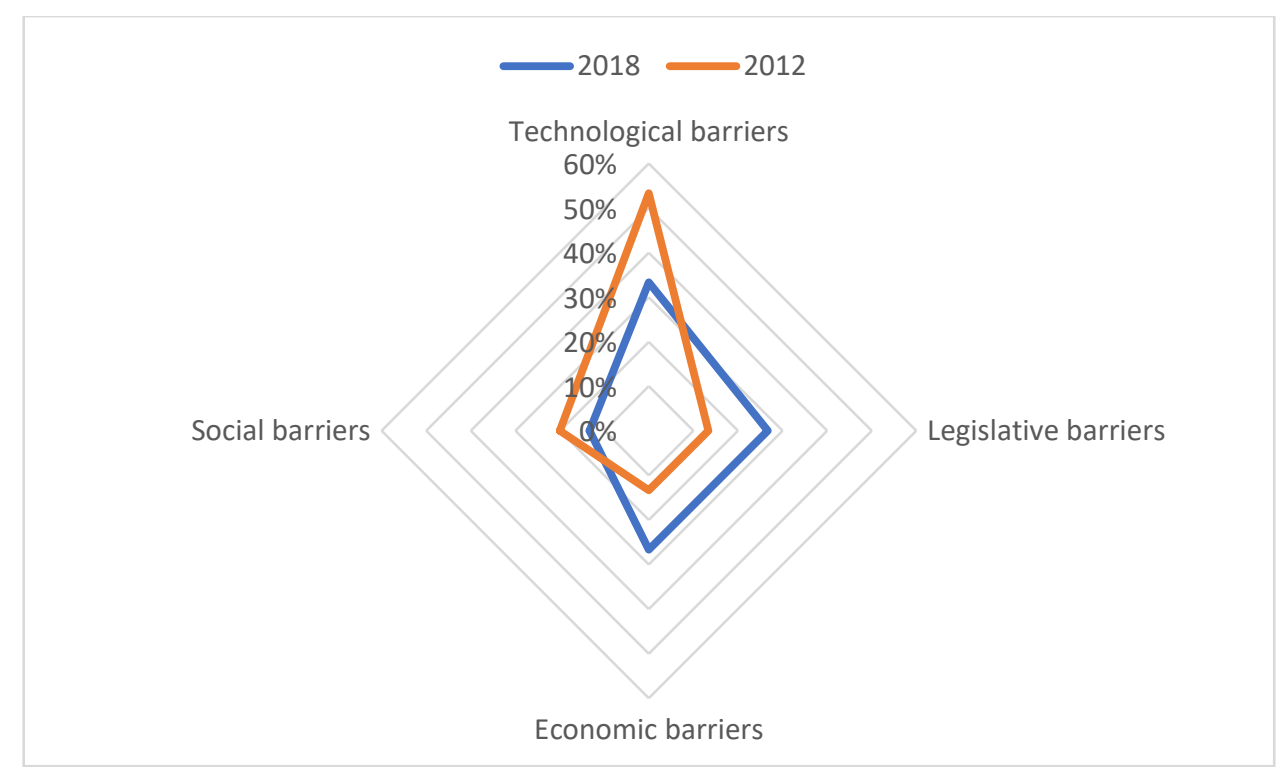

Figure 10 - Barriers on plastic circularity in the plastic industry (C22 NACE code) in Emilia Romagna region $(2012,2018)$ - Microscale analysis

At the manufacturing level, technical and technological barriers can affect both products and processes. Quality issues are the main concern as it relates to the limited usage of recycled materials among converters. In particular, the presence of some impurities can cause some problems in relation with the correct process temperature, causing also a fall in mechanical performance. In addition, some additives, that are not altered during mechanical recycling and persist at high temperatures, may significantly modify the physical properties of recycled plastics affecting strength and durability but also colour and other esthetical implications (Pivnenko, 2016).

Legislative barriers are mainly related to:

- REACH Regulation that sets out criteria for classifying a substance as a "substance of very high concern" (SVHC) (European Parliament and of the Council, 2006).

- RoHS Directive that regulates the presence of Lead, Mercury, Cadmium, Hexavalent chromium, Polybrominated biphenyls (PBB) and Polybrominated diphenyl ethers (PBDE) in products (European Parliament and of the Council, 2017)

Additional barriers deal with the prohibition regarding the use recycled plastics in some technical applications, such as medical ones. Economic constraints are mainly related to limited availability for specific polymers and lack of constant demand. The high costs, especially for acceptable quality of certain recycled polymers, is another reasonable issue. Social and cultural barriers are expressed as a hostility towards innovative materials and products in some cases and as an inert attitude towards new business models in other cases. Inert behaviour and the lack of interest in innovative business and materials, limits R\&D activities, and consequently the exit from the fossil-based market. 


\subsubsection{Barriers to plastic circularity: a Meso-scale analysis}

Barriers at company level, reflect a more complicated framework and background regarding the entire plastics industry. The frame of reference becomes more complex when the material under investigation is characterized by a multitude of formulations and applications. In addition, the influence of oil price on virgin, and consequently, recycled plastics, restricts the demand for sustainable materials.

The insufficient quality of recycled polymers composes the problems regarding the presence of non-recyclable and non-target materials in current plastic-based products. In packaging applications, the introduction of a functional barrier (Lange and Wyser., 2003) leads to the materials being rejected for recycling. In the automotive sector, the necessity to lighten vehicles has increased the manufacturing of fibre-reinforced and plastic based components, challenging the disassembly process. Within the ICT market, the demand for more performant devices has complicated design and consequently, refurbishment. These examples are some of critical issues affecting the EoL performance. The most affected sectors are EE and automotive in which the presence of composites materials and dangerous substances may be released to the environment. In fact, the presence of some impurities and their removal process add costs and reduce the competitiveness of recycled plastics (Villanueva and Eder, 2014). The increasing consumption of chemical substances with significant uncertainties on hazard properties and on unintentional releases, has also created pressure on health protection to such a point that policy has reacted by hindering the use of recycled polymers in specific applications. Controls for contaminants in the waste stream is typical in EE sector: examples of materials which can be found in electrical and electronic waste (WEEE) include base metals, precious metals, and rare earth elements - REEs (Hagelüken and Corti., 2010). Furthermore, engineering plastics and other organics, hazardous substances, such as brominated flame retardants, lead, beryllium, arsenic and other materials, can be found. In addition, although the main plastics production is dominated by thermoplastics, thermoset plastic applications are significant (especially PUR applications) but technologies for recycling thermosets are limited, thus limiting the possible use of recycled materials in sector where these polymers are widely used.

From an economic point of view, the uncompetitive prices of recycles than virgin polymers reflect the fluctuation of oil price first and the waste management cost secondly. In addition, the absence of a constant volume of plastic waste and, at the same time, the difficulty to manage irregular and significant peaks of waste are responsible for additional costs causing market vulnerability. It follows that more communication between plastics converters and plastic recyclers have to be activated to overcome barriers.

Social barriers are taken into consideration because of customers' disinterest towards sustainable purchase. Manufactures are also sceptical about using resources coming from waste (Polymer Comply Europe, 2017). Cultural barriers are represented by the lifestyles of consumers and changes in living standards. For example, many products such as home cleaning products and liquid soap currently come in single-use bottles and consist mainly of water with a small volume of 'active ingredients' (World Economic Forum, 2017). Technically, it would 
be possible to provide customers with refills in dissolvable sachets that can be mixed with water in refillable bottles at home. However, consumers can give more importance to ease of use than to reducing environmental impact or lower purchase price. Furthermore, the fragmentation of the current collection and sorting systems is also particularly relevant: citizens are confused about how plastics should be disposed of and the collection and sorting infrastructures adopted by the municipalities are misaligned with the packaging design.

Finally, with regard to legislative barriers, the current regulatory framework does not yet adequately support the use of secondary plastics. Even if the current recycling process can be assumed as EoL scenario to assess EoL criteria thus producing secondary plastics, critical issues regarding the scrap's management are always present. Industrial waste can circulate without compelling requirements but the boundary between waste and not-waste status is very labile, entering into the illegal waste management area. Other legislative limits are related to disharmonized legislation between chemical, waste and products. A clearer and harmonised legislation occurs to overcome problem on waste, secondary materials and by-products management.

Some of the barriers are summarized in Table 1. 


\begin{tabular}{|c|c|c|c|c|c|}
\hline BARRIERS at mesoscale level & Plastic production & Plastic compound & Plastic convertion & Plastic distribution and use & Plastic recycling \\
\hline \multirow{5}{*}{ Techical-technological barriers } & & & & $\begin{array}{l}\text { Contamination of post consumer } \\
\text { plastic and secondary materials }\end{array}$ & $\begin{array}{l}\text { Lack of innovation on recycling plant } \\
\text { a }\end{array}$ \\
\hline & & i & ! & Low efficiency on collection system & $\begin{array}{l}\text { Low efficiency on sorting system } \\
\text { L }\end{array}$ \\
\hline & & & $\begin{array}{l}\text { Lack of mechanical performance in } \\
\text { recycled plastic-based products }\end{array}$ & & Recycling challenge for LD polimer-based films \\
\hline & & & $\begin{array}{l}\text { Incompatibility of recycled plastics! } \\
\text { with product manufacturing } \\
\text { process }\end{array}$ & & Recycling challenge for composite materials \\
\hline & \multicolumn{3}{|c|}{ Lack of information on recycled plastic composition, including hazardous substances } & & $\begin{array}{l}\text { Recycling challenge for thermoset polymers } \\
\text { Res }\end{array}$ \\
\hline \multirow{6}{*}{ Legislative barriers } & \multicolumn{5}{|c|}{ Unclear definition and management for waste (pre and post consumer waste), by-product and secondary materials } \\
\hline & \multicolumn{3}{|c|}{$\begin{array}{l}\text { Lack of harmonization on evaluating safety of recycled process for plastic food } \\
\text { contact materials }\end{array}$} & & 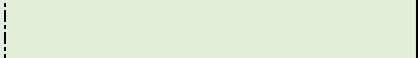 \\
\hline & \multicolumn{3}{|c|}{$\begin{array}{l}\text { Safety requirements for highly technical products and hazardous components and } \\
\text { material issue }\end{array}$} & & $\vdots$ \\
\hline & & i & Rigid certification for EE products & & i \\
\hline & & & Rigid food contact legislation & & 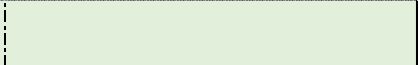 \\
\hline & Missing guidance $f$ & sign and lack of sup & oort for scaling up circular models & 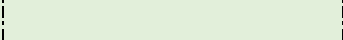 & 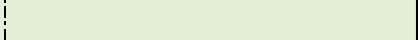 \\
\hline \multirow{11}{*}{ Socio-cultural barriers } & & & $\begin{array}{l}\text { Resistance to change among } \\
\text { product manufaturers }\end{array}$ & & $\begin{array}{l}\text { High costs of collecting, sorting and processing } \\
\text { waste plastics (influencing the secondary } \\
\text { plastics costs) }\end{array}$ \\
\hline & & 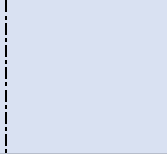 & $\begin{array}{c}1 \\
\vdots \\
\vdots \\
\vdots \\
\vdots \\
\vdots \\
\vdots \\
\vdots\end{array}$ & $\begin{array}{l}\text { Irregular and significant peaks of } \\
\text { waste market }\end{array}$ & $\begin{array}{l}\vdots \\
\vdots \\
\vdots \\
\vdots \\
\vdots \\
\vdots\end{array}$ \\
\hline & \multicolumn{3}{|c|}{$\begin{array}{l}\text { Vulnerable markets for recycled plastics (depending on oil price and recycled plastics } \\
\text { availability) }\end{array}$} & $\begin{array}{l}\text { Limited resilience of the sector to } \\
\text { market shocks }\end{array}$ & $\begin{array}{l}\text { Competition between recycling and energy } \\
\text { from waste }\end{array}$ \\
\hline & \multicolumn{3}{|c|}{ Lack of incentives for performing new circular materials and products } & t & $\vdots$ \\
\hline & \multicolumn{3}{|c|}{ High risk for moving from linear to circular production process } & i & 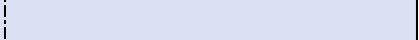 \\
\hline & \multicolumn{3}{|c|}{ Lack of support for scaling up circular eocnomy models, especially for SMEs } & i & 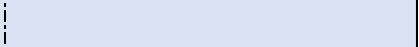 \\
\hline & \multicolumn{3}{|c|}{ Hostility in the direction of innovative materials } & Unsustainable cultural behaviour & ! \\
\hline & & & $\begin{array}{l}\text { Inert attitude toward the client } \\
\text { request }\end{array}$ & $\begin{array}{l}\text { Low consciousness on single-use } \\
\text { packaging consumption }\end{array}$ & \\
\hline & & & & $\begin{array}{l}\text { Low consciousness on correct waste } \\
\text { disposal }\end{array}$ & \\
\hline & & & 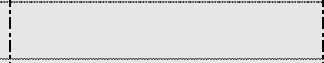 & $\begin{array}{l}\text { Business as usual (BAU) model } \\
\text { diffusion }\end{array}$ & 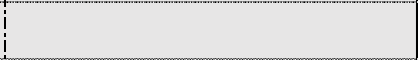 \\
\hline & & & & $\begin{array}{l}\text { Customers' disinterest toward } \\
\text { secondary plastics }\end{array}$ & illegal waste trafficking \\
\hline
\end{tabular}

Table 1 - Some of the barriers to plastic circularity - Mesoscale analysis

Box 1 zooms in at one of the barriers, namely lack of information on recycled plastic composition, including hazardous substances, as an example of their scope. 
Box 1- Barrier example: lack of information on recycled plastic composition, including hazardous substances

Among the various barriers seen, the overall lack of information on recycled plastic composition is a pressing one. This is a serious problem, since recycled plastics may entail hazardous substances. These, in turn, may pose a serious threat to the aquatic and terrestrial ecosystems, as well as to human health. In order to address the need for sustainable solutions for bio-based plastics on land and sea, the Horizon 2020 project "Developing and Implementing Sustainability-Based Solutions for BioBased Plastic Production and Use to Preserve Land and Sea Environmental Quality in Europe" (Acronym: Bio-Plastics Europe) led by the European School of Sustainability Science and Research at the Hamburg University of Applied Sciences in Germany, has been initiated. The project will primarily focus on novel ideas and solutions that include consideration to sustainable feedstocks and materials, and manufacturing and recycling processes. But it will also examine matters related to consumer behaviour and systems (for example legal, fiscal and policy systems) set within a context of environmental and health benefits.

The next section of this paper deals with some best practice from the packaging industry.

\subsection{Best practice from the packaging industry}

In 2018, around 50\% of investigated companies have increased the rate of usage of non-virgin plastics. Most of them work in the packaging sector. The Plastics Strategy, the Chinese import ban, the amendment on packaging and packaging waste as well as the evolution on packaging design requirements and the more sustainable behaviour adopted by consumers have pushed packaging companies to change their business models (Brooks et al., 2018; European Parliament and the Council of the European Union, 2018a-b). A more sustainable production (and consumption) model, which integrates new innovative technologies and products for efficient collaboration with recyclers and designers is now being used.

Packaging plastics, and the polymers commonly used in packaging, represent the majority of plastics that are collected for recycling due to their widespread use for single-use packaging. The different use of polymers in packaging products are illustrated in Figure 11, below. 


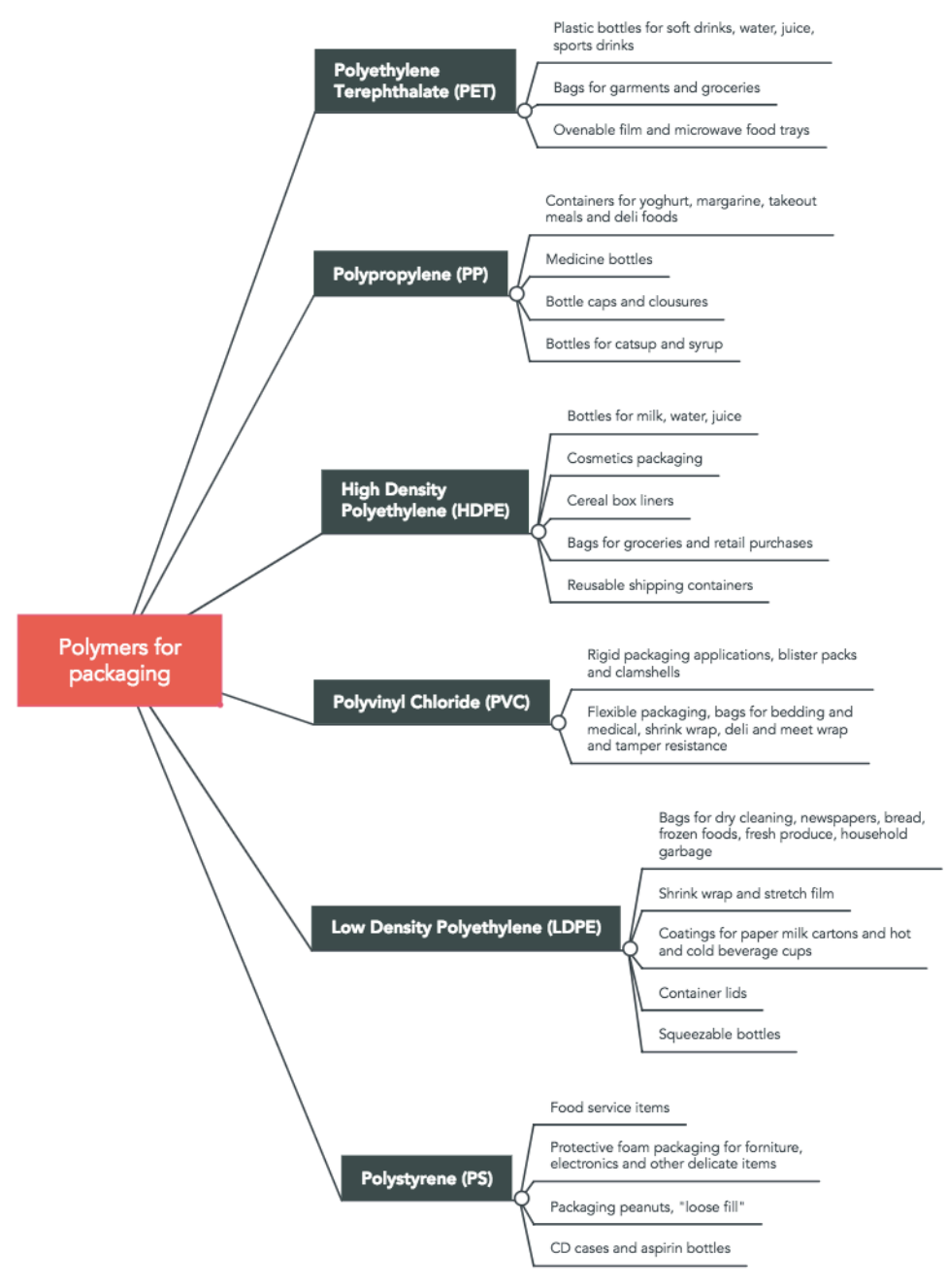

Figure 11- Polymers for packaging applications

Even if PE has the highest share of production of any polymer type (Geyer et al.,2017), PET is the most commonly recycled polymer (Awaja and Pavel., 2005). PP is not recycled at the same level as PET, PE-HD and PE-LD (OECD, 2018). It follows that packaging one of the most preferable experimental application types to promote the circularity of plastics. From the legislative point of view, the European Food Safety Authority (EFSA) has adopted scientific opinions on the safety of processes to recycle PET for use in food contact materials thus supporting Regulation (EC) $n^{\circ} 1935 / 2004$ that sets out the general principles of safety and inertness for all Food Contact Materials (FCMs), Regulation (EC) 282/2008 on recycled plastic materials and articles intended to come into contact with foods, and Regulation (EU) $n^{\circ}$ 10/2011 that defines criteria for the composition of new plastic materials (European Parliament And Of The Council, 2004; Commission Regulation, 2008; 2011). The availability of postconsumer packaging waste is also served by a good and monitored management of its end-oflife.

From an economic point of view, the benefits from a green marketing have intensified the demand for recycled plastics. Nowadays, a lot of packaging is manufactured by recycled or 
biodegradable polymers. The positive influence on packaging applications has also reflected the regional value chain where collaborative matchmaking between packaging manufactures and recyclers is highlighted. Among respondents of the regional investigation, the most important innovation on plastic circularity comes from the recovery and cleaning of used PET food packs for processing into next generation food containers. This model has been implemented thanks to a joint venture between a food packaging producers and a recycling firm. The synergy allows to internally manage the supply of PET and control the entire process, starting from post-consumption material sorting to the subsequent selection, washing, grinding, extrusion and thermoforming of r-PET food packaging.

PET collection and sorting become more and more important to ensure a constant volume of secondary raw materials production. However, the valorisation of PET for other uses, as the replacement of cotton in the fibre industry (especially in the Chinese firms), has created a relatively high value on international markets over recent years. (WRAP, 2016). Consequently, post-consumer PET bottles prices have risen steadily since mid-January to the end of the year with the price midpoint for colourless reaching $€ 422.50 /$ tonne in November as mixed coloured firmed to $€ 302.50 /$ tonne. While the colourless R-PET flake midpoint rose to $€ 930 /$ tonne with mixed coloured at $€ 642.50 /$ tonne in November as food grade R-PET pellets hit $€ 1,190 /$ tonne $^{2}$. The increase on the price is also due to a shortage of PET bottles, as an expression of the cultural behaviour development toward sustainability. When economic and legislative barriers are outdated, establishing a closed plastics loop requires a value chain partner to take on the role of coordinator, safeguarding the quality of the process along the entire value chain while developing the skills and aligning the interests of all parties involved (Ellen Mac Arthur Foundation, 2017).

\section{Future challenges to foster plastic circularity}

In the plastics sector, circular economy principles have been applied for years, more in terms of implementation of energy valorisation than of polymers remanufacturing. However, many of the challenges are related to the production system to make the plastic industry more sustainable.

The use of recycled plastics is marginal compared to virgin plastics across all plastic types due to a range of technological and market factors. Performance tests on recycled plastics are usually lower than in virgin plastics. Different resin composition and level of contamination gets challenge in the EoL management. Moreover, the difficulty in finding high quality recycled plastics in the local market increases the price for the associated transport costs. Even if the practice is getting wider, recycled plastics are not commonly used in food packaging owing to directives on food safety and hygiene standards. Another limit on the use of recycled plastics is that plastic processors require large quantities of recycled plastics, manufactured to strictly controlled specifications at a competitive price in comparison to virgin polymers.

\footnotetext{
${ }^{2}$ All of these prices are on a free delivered (FD) northwest Europe (NWE) basis and the majority of these midpoints far surpassed any peaks seen in 2016.
} 
Therefore, collection, sorting, and general waste management become essential pre-actions to maximizing the polymers separation, obtaining the maximum level of materials purity. At the same time, the recycling market must increase, making regions self-determined and selfsufficient. To maximize the recycled plastic demand, it is necessary to establish a strong connection between recyclers and converters, optimizing needs on the prescription for various applications.

Some problems are also related to composite plastic materials and non-recyclable polymers. Recycling processes are very often hampered by inseparable polymer composites, an unnecessary use of additives or combining plastics with other materials (paper, metal, fibres) in a way that does not allow for an easy separation. Recycling of plastics does not begin with collection but rather with the eco-design of products, in a life cycle thinking approach. For nonrecyclable polymers, even if some thermosetting polymers can be converted relatively easily back to their original monomer, such as PUR, the more common thermosetting resins such as PS and epoxy are not easy to be depolymerised to their original constituents. In Europe, approximately 1 million tonnes of composites are manufactured each year (PlasticsEurope. 2017). Eco-design and re-design of products, in a circular economy perspective, becomes important by limiting unrecyclable multi-material products, dangerous substances and coloured and opaque materials. However, the perceived lack of recyclability is now increasingly important and seen as a key barrier to the development or even continued use of composite materials in some markets (Sims, 2001). Challenges for thermosetting polymers is limiting as much as possible the use of non-recyclable polymers substituting them with more sustainable materials.

It is necessary to highlight that the common and current approach seems to be not able to achieve the proposed recycling target of $55 \%$ by 2025 . To create a more circular economy, innovative approaches, new ideas and a whole life cycle thinking are required. This ambition has inspired several important initiatives in Europe. The commitment of the European Commission, through the amendments of the Directive on waste (Directive 2018/851/UE) and packaging and packaging waste (Directive 2018/852/UE) drives the transition toward sustainable innovation oriented to a material-specific lifecycle approach (European Parliament and the Council of the European Union., $2018 \mathrm{a}-\mathrm{b}$ ). In fact, the actual EU policy framework is contributing to make the environment regulations more effective, pushing multidimensional supply chain model and strategic collaboration based competition model (Gurtoo and Antony, 2007). However, without an evaluation framework or bottom-up support from the industry or the community, CE initiatives are not sustained (Winans et al., 2017). From the bottom up approach, "The New Plastics Economy" report by Ellen Mc Arthur Foundation provides a "transition strategy" for the plastic industry to re-design packaging and to introduce new models for making better use of packaging and increasing recycling rate in order to achieve $70 \%$ of packaging recycling. The main components of that approach are:

1. Create an effective after-use plastics economy by improving the economics and uptake of recycling, reuse and controlled biodegradation for targeted applications. 
2. Drastically reduce leakage of plastics into natural systems (in particular the ocean) and other negative externalities.

3. Decouple plastics from fossil feedstocks by exploring and adopting renewably sourced feedstocks.

The complex value chain of plastics will have to be changed in significant ways to create viable management approaches towards achieving environmental and economic gains will have to be identified. Plastic converters are mainly small and medium enterprises. An integrative collaboration could support the transition towards circular economy models. This will require innovative solutions and major efforts by key decision makers, plastics waste sorters, recyclers, retailers as well as consumers. PlasticsEurope announces the creation of a multi-stakeholder group platform to identify the opportunities to increase Europe's recycling and work towards ensuring the supply of high-quality recycled plastics. This initiative suggests some priority areas of work such as the development of packaging design guidelines and assessment protocols according to the principles of the circular economy; innovation in recycling processes and development of end-use markets; EU wide quality standards for sorted plastics and certification of plastic recycling operations.

The following figure (Figure 12) illustrates an alternative plastics value chain where recyclers and converters are strictly inter-linked. The overcoming of above-mentioned barriers is supported by tools such as protocols for recycling standardisation (especially for postconsumer waste) acquisition agreement, certification and labelling on the quality of recycles, thus ensuring a well-working after-use plastics economy. However, converters play a key role as well, by promoting eco-design and design for recyclability practices by a strong collaboration with stakeholders working on waste management. In this context, compounding, incinerating and landfilling act as auxiliary services.

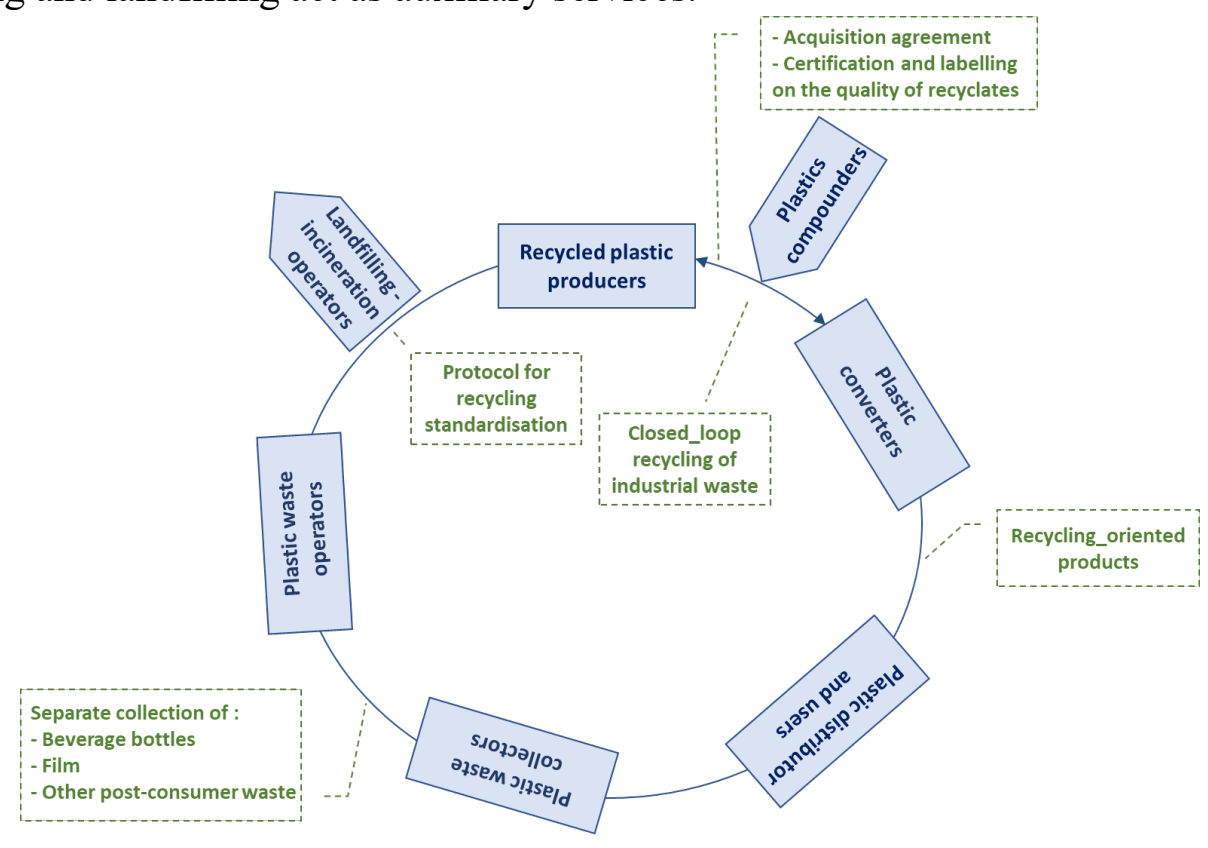

Figure 12 - Alternative plastics value chain, a simplified version 


\section{Conclusions}

Urban drainage block, negative carbon footprint, natural resources consumption, deeper ecological footprint etc. are some of the negative effects linked with improperly discarded plastic waste. Furthermore, thermal treatment of PB causes air pollution due to heavy metal (HM) evaporation and emissions (Alam, Wang, and Lu, 2018). Similarly, many agricultural soils are being contaminated by plastic pollutants, which poses a severe threat to soil and plant health, as well as food security (Brodhagen et al., 2017).

The variety in the chemical composition of plastic polymers equally complicates recycling and its disposal, further contributing to the pollution problem (Barra and Gonzalez, 2018).

Given the enormous impact that pollution caused by plastics has for life on Earth and considering the contributing causes, we need a new economic paradigm that guides investment, production and consumption choices. According to World Economic Forum and Ellen MacArthur Foundation (2017), this implies a New Plastic Economy based on the idea that plastics never become waste; rather, they return to the economy as precious technical or biological nutrients. In effect, the new plastics economy is aligned with the principles of the circular economy and the ambition to provide better economic and environmental results, drastically reducing the loss of plastics in natural systems (especially the ocean) and decouple from fossil raw materials.

There are some possible solutions. For instance, in order to realize the circular economy of plastics, it is necessary to rethink the design of plastic products and processes, making them fully recyclable. Also, we need to follow an integrated and transversal view of the global value chains of plastics, in which the recycling and reuse of plastics is emphasised, so they are not thrown away. Moreover, since it is inevitable that a significant portion of plastics will continue to be disposed of, efforts to avoid dispersion in the ocean or in the soil are needed.

Europe and the United States are home to the vast majority of companies that are relevant to the plastics industry, and in particular of companies that determine the design of plastic products and packaging, the innovation of advanced technologies in the field of separation and reprocessing, as well as in the development of bio-benign materials or of materials designed to facilitate multilayer reprocessing. Therefore, in these countries, companies should assume a global leadership to go beyond small-scale and incremental improvements, and towards achieving a systemic shift to plastics as part of the circular economy. The ability of companies to create innovation in raw materials, products, packaging, and production and distribution processes is essential. From the management point of view, a new paradigm with the environment must be considered: sustainability must be integrated in the firm rather than be considered as an externality (Aras and Crowther, 2009). Moreover, companies cannot operate as isolated organizational silos; they need more collaboration with all the stakeholders involved in the co-production of a complex outcome such as the reduction of environmental pollution. This concerns the greater integration in business-to-business relations, between consumer 
goods companies, manufacturers of plastic packaging, plastics manufacturers and companies involved in the collection, sorting and reprocessing. This issue is emphasised in the conversion industry, where SMEs are the majority.

The implications of this paper are two-fold. Firstly, it is clear that high recycling targets and a well-working secondary plastics market cannot be pursued only by industry. An important node of this circular economy network is represented by both the municipal and regional administrations, which control the post-use infrastructure and are often the centre of innovation, and local communities whose sensitivity to active citizenship values contributes to ensuring an essential social platform to achieve this goal. Secondly, no less important is the role of political decision makers in creating the institutional conditions that promote the transition to the plastics circular economy, realigning economic incentives to businesses, cities and citizens, facilitating secondary markets, setting standards and stimulating innovation.

\section{Acknowledgments}

Authors gratefully acknowledge the Consortium for innovation and technology transfer of Emilia-Romagna region (ERVET) for providing previous data to the investigation.

\section{References}

Alam, O., Wang, S., and Lu, W. (2018). Heavy metals dispersion during thermal treatment of plastic bags and its recovery. Journal of Environmental Management, 212, 367-374. https://doi.org/10.1016/j.jenvman.2018.02.034

Al-Salem, S. M., Lettieri, P., \& Baeyens, J. (2009). Recycling and recovery routes of plastic solid waste (PSW): A review. Waste Management. https://doi.org/10.1016/j.wasman.2009.06.004

Aras, G., \& Crowther, D. (2009). Making sustainable development sustainable. Management Decision. https://doi.org/10.1108/00251740910966686

Avérous, L. (2013). Handbook of Biopolymers and Biodegradable Plastics. Handbook of Biopolymers and Biodegradable Plastics. https://doi.org/10.1016/B978-1-4557-28343.00006-9

Awaja, F., \& Pavel, D. (2005). Recycling of PET. European Polymer Journal. http://doi.org/10.1016/j.eurpolymj.2005.02.005

Barra, R. and González, P. (2018). Sustainable chemistry challenges from a developing country perspective: Education, plastic pollution, and beyond. Current Opinion in Green and Sustainable Chemistry, 9, 40-44. https://doi.org/10.1016/j.cogsc.2017.12.001

Brems, A., Baeyens, J., \& Dewil, R. (2012). Recycling and recovery of post-cet alonsumer plastic solid waste in a European context. Thermal Science. http://doi.org/10.2298/TSCI120111121B

Brodhagen, M., Goldberger, J.R., Hayes, D.G., Inglis, D.A., Marsh, T.L., and Miles, C. 
(2017). Policy considerations for limiting unintended residual plastic in agricultural soils. Environmental Science \& Policy, 69, 81-

84.https://doi.org/10.1016/j.envsci.2016.12.014

Brooks, A. L., Wang, S., \& Jambeck, J. R. (2018). The Chinese import ban and its impact on global plastic waste trade. Science Advances. http://doi.org/10.1126/sciadv.aat0131

Carpenter, E. and Wolverton, S. (2017). Plastic litter in streams: The behavioral archaeology of a pervasive environmental problem. Applied Geography, 84, 93-101.

https://doi.org/10.1016/j.apgeog.2017.04.010

Chiba, S., Saito, H., Fletcher, R., Yogi, T., Kayo, M., Miyagi, S., Ogido, M., and Fujikura, K. (2018). Human footprint in the abyss: 30 year records of deep-sea plastic debris. Marine Policy. https://doi.org/10.1016/j.marpol.2018.03.022

Cole, M., Lindeque, P., Halsband, C., and Galloway, T.S. (2011). Microplastics as contaminants in the marine environment: a review. Mar. Pollut. Bull., 62, 2588-2597. https://doi.org/10.1016/j.marpolbul.2011.09.025

Commission Regulation. (2008). Commission Regulation (EC) No 282/2008 of 27 March 2008 on recycled plastic materials and articles intended to come into contact with foods and amending Regulation (EC) No 2023/2006

Commission Regulation. (2008). Commission Regulation (EU) No 10/2011 of 14 January 2011 on plastic materials and articles intended to come into contact with food

Debrot, A.O., Van Rijn, J., Bron, P.S., De León, R. (2013). A baseline assessment of beach debris and tar contamination in Bonaire, Southeastern Caribbean. Mar. Pollut. Bull., 71, 325-329. https://doi.org/10.1016/j.marpolbul.2013.01.027

Deloitte. (2015). Increased EU Plastics Recycling Targets: Environmental, Economic and Social Impact Assessment. Available online: https://www.plasticsrecyclers.eu/sites/default/files/BIO_Deloitte_PRE_Plastics\%20R ecycling\%20Impact_Assesment_Final\%20Report.pdf

Di Gregorio, B. E. (2009). Biobased Performance Bioplastic: Mirel. Chemistry and Biology. http://doi.org/10.1016/j.chembiol.2009.01.001

Dris, R., Gasperi, J., Saad, M., Mirande, C., and Tassin, B. (2016). Synthetic fibers in atmospheric fallout: a source of microplastics in the environment? Mar. Pollut. Bull., 104 (1-2), 290-293. https://doi.org/10.1016/j.marpolbul.2016.01.006

Eagle, L., Hamann, M., and Low, D.R. (2016). The role of social marketing, marine turtles and sustainable tourism in reducing plastic pollution. Marine Pollution Bulletin, 107 (1), 324-332. https://doi.org/10.1016/j.marpolbul.2016.03.040

Eastwood, M. D., Haapala, K. R. (2015) A unit process model based methodology to assist product sustainability assessment during design for manufacturing. Journal of Cleaner Production, Volume 108, Part A, Pages 54-64. Htt ps://doi.org/10.1016/j.jclepro.2015.08.105 
Ellen MacArthur (2012), Report Towards the Circular Economy. Available online: https://www.ellenmacarthurfoundation.org/publications/towards-the-circulareconomy-vol-1-an-economic-and-business-rationale-for-an-accelerated-transition

Ellen Mac Arthur Foundation. (2017). Scaling recycled plastics across industries. Available online:https://www.ellenmacarthurfoundation.org/assets/downloads/ce100/ScalingRecycled-Plastics-across-Industries.pdf

Eriksen, M., Maximenko, N., Thiel, M., Cummins, A., Lattin, G., Wilson, S., Hafner, J., Zellers, A., and Rifman, S. (2013). Plastic pollution in the South Pacific subtropical gyre. Mar. Pollut. Bull., 68, 71-76. https://doi.org/10.1016/j.marpolbul.2012.12.021

European Bioplastics. (2017). Bioplastic Market Data 2017. European Bioplastics.

Availableonline:https://docs.europeanbioplastics.org/publications/market_data/2017/ Report Bi oplastics Market Data 2017.pdf

European Commission. (2018a). A European Strategy for Plastics in a Circular Economy. https://doi.org/10.1021/acs.est.7b02368

European Commission. (2018b). Report from The Commission To The European Parliament And The Council on the impact of the use of oxo-degradable plastic, including oxodegradable plastic carrier bags, on the environment. Available online: http://ec.europa.eu/environment/circular-economy/pdf/oxo-plastics.pdf

European Parliament and of the Council. (2004). Commission Regulation (EC) No 1935/2004 of The European Parliament And Of The Council of 27 October 2004 on materials and articles intended to come into contact with food and repealing Directives 80/590/EEC and $89 / 109 /$ EEC

European Parliament and of the Council. (2006). Regulation (EC) No 1907/2006 of the European Parliament and of the Council of 18 December 2006 concerning the Registration, Evaluation, Authorisation and Restriction of Chemicals (REACH), establishing a European Chemicals Agency, amending Directive 1999/45/EC and repealing Council Regulation (EEC) No 793/93 and Commission Regulation (EC) No 1488/94 as well as Council Directive 76/769/EEC and Commission Directives 91/155/EEC, 93/67/EEC, 93/105/EC and 2000/21/EC

European Parliament and the council of the European Union. (2008). Directive 2008/98/EC of the European Parliament and of the Council of 19 November 2008 on waste and repealing certain Directives. Official Journal of the European Union. https://doi.org/2008/98/EC.; 32008L0098

European Parliament and of the Council. (2017). Directive (EU) 2017/2102 of the European Parliament and of the Council of 15 November 2017 amending Directive 2011/65/EU on the restriction of the use of certain hazardous substances in electrical and electronic equipment

European Parliament and the Council of the European Union. (2018a). Directive (EU) 
2018/851 of the European Parliament and of the Council of 30 May 2018 amending Directive 2008/98/EC on waste.

European Parliament and the Council of the European Union. (2018b). Directive (EU) 2018/852 of the European Parliament and of the Council of 30 May 2018 amending Directive 94/62/EC on packaging and packaging waste

Fishman, A., \& Rob, R. (2000). Product innovation by a durable-good monopoly. RAND Journal of Economics. http://doi.org/10.2307/2601039

Geissdoerfer, M., Savaget, P., Bocken, N. M. P., \& Hultink, E. J. (2017). The Circular Economy - A new sustainability paradigm? Journal of Cleaner Production. https://doi.org/10.1016/j.jclepro.2016.12.048

Geyer, R., Jambeck, J. R., \& Law, K. L. (2017). Production, use, and fate of all plastics ever made. Science Advances. http://doi.org/10.1126/sciadv.1700782

Ghisellini, P., Cialani, C., \& Ulgiati, S. (2016). A review on circular economy: The expected transition to a balanced interplay of environmental and economic systems. Journal of Cleaner Production. https://doi.org/10.1016/j.jclepro.2015.09.007

Goodship, V. (2007). Plastic recycling. Science Progress. http://doi.org/10.3184/003685007X228748

Gurtoo, A., \& Antony, S. J. (2007). Environmental regulations: Indirect and unintended consequences on economy and business. Management of Environmental Quality: An International Journal. https://doi.org/10.1108/14777830710826676

Hagelüken, C., \& Corti, C. W. (2010). Recycling of gold from electronics: Cost-effective use through "design for recycling." Gold Bulletin. https://doi.org/10.1007/BF03214988

Hall, M. R., Priestley, A., \& Muster, T. H. (2018). Environmental Life Cycle Costing and Sustainability: Insights from Pollution Abatement and Resource Recovery in Wastewater Treatment. Journal of Industrial Ecology. https://doi.org/10.1111/jiec.12636

Harding, K. G., Gounden, T., \& Pretorius, S. (2017). "Biodegradable" Plastics: A Myth of Marketing? Procedia Manufacturing. http://doi.org/10.1016/j.promfg.2016.12.027

Harper, C. A. (2005). Handbook of Plastic Processes. Handbook of Plastic Processes. http://doi.org/10.1002/0471786586

Jambeck, J.R., Geyer, R., Wilcox, C., Siegler, T.R., Perryman, M., Andrady, A., Narayan, R., and Law, K.L. (2015). Plastic waste inputs from land into the ocean. Science, 347 (2015), 768-771. https://doi.org/10.1126/science. 1260352

Karlsson, T.M., Arneborg, L., Broström, G., Almroth, B.C., Gipperth, L., and Hassellöv, M. (2018). The unaccountability case of plastic pellet pollution. Marine Pollution Bulletin, 129(1), 52-60. https://doi.org/10.1016/j.marpolbul.2018.01.041 
Kaya, T., \& Kahraman, C. (2011). An integrated fuzzy AHP-ELECTRE methodology for environmental impact assessment. Expert Systems with Applications. https://doi.org/10.1016/j.eswa.2011.01.057

Kirchherr, J., Reike, D., \& Hekkert, M. (2017). Conceptualizing the circular economy: An analysis of 114 definitions. Resources, Conservation and Recycling. https://doi.org/10.1016/j.resconrec.2017.09.005

Kühn, S., Rebolledo, E.L.B., and van Franeker, J.A. (2015). Deleterious effects of litter on marine life. Marine Anthropogenic Litter, Springer, 75-116. https://doi.org/10.1007/978-3-319-16510-3_4

Kwon, B.G., Chung, S.Y., Park, S.S., and Saido, K. (2018). Qualitative assessment to determine internal and external factors influencing the origin of styrene oligomers pollution by polystyrene plastic in coastal marine environments. Environmental Pollution, 234, 167-173. https://doi.org/10.1016/j.envpol.2017.11.046

Landon-Lane, M. (2018). Corporate social responsibility in marine plastic debris governance. Marine Pollution Bulletin, 127, 310-319. https://doi.org/10.1016/j.marpolbul.2017.11.054

Lange, J., \& Wyser, Y. (2003). Recent Innovations in Barrier Technologies for Plastic Packaging - A Review. Packaging Technology and Science. https://doi.org/10.1002/pts.621

Lavers, J.L. and Bond, A.L. (2017). Exceptional and rapid accumulation of anthropogenic debris on one of the world's most remote and pristine islands. Proc. Natl. Acad. Sci. Unit. States Am. (2017). https://doi.org/10.1073/pnas.1619818114

Lea, W. R. (1996). Plastic incineration versus recycling: A comparison of energy and landfill cost savings. Journal of Hazardous Materials. https://doi.org/10.1016/03043894(95)00117-4

Leal Filho, W., Havea, P.H., Balogun, A.L., Boenecke, J., Maharaj, A.A., Ha'apio, M., \& Hemstock, S.L. (2019a). Plastic debris on Pacific Islands: Ecological and health implications. Science of the Total Environment, 670, 181-187

Leal Filho, W., Saari, U., Fedoruk, M., Iital, A., Moora, H., Klöga, M., Voronova, V. (2019b) An overview of the problems posed by plastic products and the role of extended producer responsibility in Europe. In Journal of Cleaner Production, Volume 214, 20 March 2019, Pages $550-558$.

Li. C. (2017). Polymer materials and sustainable development. J Beijing Normal Univ (Social Sci Ed) 2001;1:123e7.

Lieder, M., \& Rashid, A. (2016). Towards circular economy implementation: A comprehensive review in context of manufacturing industry. Journal of Cleaner Production. https://doi.org/10.1016/j.jclepro.2015.12.042

López-Rubio, A., Almenar, E., Hernandez-Muñoz, P., Lagarón, J. M., Catalá, R., \& Gavara, 
R. (2004). Overview of active polymer-based packaging technologies for food applications. Food Reviews International. http://doi.org/10.1081/FRI-200033462

Lu, Y. et al. (2016). Uptake and accumulation of polystyrene microplastics in zebrafish (Danio rerio) and toxic effects in liver. Environ. Sci. Technol., 50 (7), 4054-4060.

https://doi.org/10.1021/acs.est.6b00183

Mani, T., Hauk, A., Walter, U., \& Burkhardt-Holm, P. (2015). Microplastics profile along the Rhine River. Scientific Reports. https://doi.org/10.1038/srep17988

Miller, R.Z., Watts, A.J.R., Winslow, B.O., Galloway, T.S., and Barrows, A.P.W. (2017). Mountains to the sea: River study of plastic and non-plastic microfiber pollution in the northeast USA. Marine Pollution Bulletin, 124 (1), 245-251. https://doi.org/10.1016/j.marpolbul.2017.07.028

Monteiro, R.C.P., Ivar do Sul, J.A., and Costa, M.F. (2018). Plastic pollution in islands of the Atlantic Ocean. Environmental Pollution, 238, 103-110. https://doi.org/10.1016/j.envpol.2018.01.096

Muñoz, I., Rieradevall, J., Domènech, X., \& Gazulla, C. (2006). Using LCA to assess ecodesign in the automotive sector: Case study of a polyolefinic door panel. International Journal of Life Cycle Assessment. https://doi.org/10.1065/lca2005.05.207

Napper, I.E., Bakir, A., Rowland, S.J., and Thompson, R.C. (2015). Characterisation, quantity and sorptive properties of microplastics extracted from cosmetics. Mar. Pollut. Bull., 99 (1-2), 178-185. https://doi.org/10.1016/j.marpolbul.2015.07.029

Nascimento, L. F., Trevisan, M., Figueiró, P. S., \& Bossle, M. B. (2010). PET Bottle Recycling Chain: opportunities for the generations of employment and income. Greener Management International. http://doi.org/10.2307/greemanainte.56.43

Ng, E.L., Lwanga, E.H., Eldridge, S.M., Johnston, P., Hu, H.W., Geissen, V., and Chen, D. (2018). An overview of microplastic and nanoplastic pollution in agroecosystems. Science of The Total Environment, 627, 1377-1388. https://doi.org/10.1016/j.scitotenv.2018.01.341

OECD. (2018). Improving Markets for Recycled Plastics: Trends, Prospects and Policy Responses. Policy Highlights. OECD Publishing. https://doi.org/10.1787/9789264301016-en

Orhan Y, Hrenovic J, Buyukgungor H. (2004). Biodegradation of plastic compost bags under controlled soil conditions. Acta Chim Slov 2004;51:579e88.

Ozdemir, M., \& Floros, J. D. (2004). Active food packaging technologies. Critical Reviews in Food Science and Nutrition. http://doi.org/10.1080/10408690490441578

Pettipas, S., Bernier, M., and Walker, T.R. (2016). A Canadian policy framework to mitigate plastic marine pollution. Marine Policy, 68, 117-122. Marine Policy. https://doi.org/10.1016/j.marpol.2016.02.025 
Pivnenko, K., Eriksen, M. K., Martín-Fernández, J. A., Eriksson, E., \& Astrup, T. F. (2016). Recycling of plastic waste: Presence of phthalates in plastics from households and industry. Waste Management. https://doi.org/10.1016/j.wasman.2016.05.014

PlasticsEurope. (2017). Plastics - the Facts 2017. https://www.plasticseurope.org/application/files/5715/1717/4180/Plastics the facts_2 017 FINAL_for_website one page.pdf

PlasticsEurope. (2015). Plastics - the facts 2015. https://www.plasticseurope.org/application/files/3715/1689/8308/2015plastics the fa cts 14122015.pdf

Polymer Comply Europe. (2017). The Usage of Recycled Plastics Materials by Plastics Converters in Europe A qualitative European industry survey Available online: https://www.nrk.nl/Content/Files/file/Downloads/rPM\%20Survey\%20Report $\% 20$ $\% 20$ Netherlands $\% 20-\% 20$ combined $\% 20$ tables $\% 20-\% 20$ compressed $\% 20$ v.2.pdf

PWMI. (2016). An Introduction to Plastic Recycling. Plastic Waste Management Institute.

Ramaswamy, V. and Sharma, H.R. (2011). Plastic bags - threat to environment and cattle health: a retrospective study from Gondar City of Ethiopia. IIOAB J. Special Issue Environ. Manage. Sustain. Dev., 2 (1), 7-12

Ragosta, G., Musto, P., Martuscelli, E., Russo, P., \& Zeloni, L. (2000). Recycling of plastic car components: the case of a multilayer item based on polypropylene. Journal of Materials Science. https://doi.org/10.1023/A:1004808809422

Rigamonti, L., Grosso, M., Møller, J., Martinez Sanchez, V., Magnani, S., \& Christensen, T. H. (2014). Environmental evaluation of plastic waste management scenarios. Resources, Conservation and Recycling. http://doi.org/10.1016/j.resconrec.2013.12.012

Raworth, K. (2017). A Doughnut for the Anthropocene: humanity's compass in the 21st century. The Lancet Planetary Health. https://doi.org/10.1016/s2542-5196(17)300281

Rosato, D. V., Rosato, D. V., \& Rosato, M. G. (2000). Injection molding handbook. Kluwer Academic Publisher. http://doi.org/10.1007/978-1-4615-4597-2

Rossi, M., Germania, M., Zamagnibc, A. (2015) Review of ecodesign methods and tools. Barriers and strategies for an effective implementation in industrial companies. Journal of Cleaner Production, 129, 361-373.

https://doi.org/10.1016/j.jclepro.2016.04.051

S.J., P. (2006). Recycling technologies for thermoset composite materials - current status. The 2nd International Conference: Advanced Polymer Composites for Structural Applications in Construction. http://doi.org/10.1016/j.compositesa.2005.05.030

Sadat-Shojai, M., \& Bakhshandeh, G. R. (2011). Recycling of PVC wastes. Polymer Degradation and Stability. http://doi.org/10.1016/j.polymdegradstab.2010.12.001 
Sandrameli, S.M. (2016). Thermal/catalytic cracking of liquid hydrocarbons for the production of olefins: A state-of-the-art review II: Catalytic cracking review. Fuel. https://doi.org/10.1016/j.fuel.2016.01.047

Seltenrich, N. (2015). New link in the food chain? Marine plastic pollution and seafood safety. Environ. Health Perspect., 123, 34-41. https://doi.org/10.1289/ehp.123-A34

Setälä, O., Norkko, J., and Lehtiniemi, M. (2016). Feeding type affects microplastic ingestion in a coastal invertebrate community. Mar. Pollut. Bull., 102 (1), 95-101. https://doi.org/10.1016/j.marpolbul.2015.11.053

Silva, A.B., Costa, M.F., and Duarte, A.C. (2018). Biotechnology advances for dealing with environmental pollution by micro(nano)plastics: Lessons on theory and practices. Current Opinion in Environmental Science \& Health, 1, 30-35. https://doi.org/10.1016/j.coesh.2017.10.005

Sims G, Bishop G. UK Polymer composites sector-competitive analysis and foresight study. Final report, Published by NPL Materials. Available online: https://avaloncsl.files.wordpress.com/2013/01/dti-composites-foresight-2001.pdf

Singh, B., \& Sharma, N. (2008). Mechanistic implications of plastic degradation. Polymer Degradation and Stability. https://doi.org/10.1016/j.polymdegradstab.2007.11.008

Sussarellu, R. et al. (2016). Oyster reproduction is affected by exposure to polystyrene microplastics. Proc. Natl. Acad. Sci., 113 (9), 2430-2435. https://doi.org/10.1073/pnas.1519019113

Vieira, M. G. A., Da Silva, M. A., Dos Santos, L. O., \& Beppu, M. M. (2011). Natural-based plasticizers and biopolymer films: A review. European Polymer Journal. https://doi.org/10.1016/j.eurpolymj.2010.12.011

Villanueva, A., \& Eder, P. (2014). End-of-Waste Criteria for waste plastic for conversion. luxemburg. https://doi.org/10.2791/13033

Villarrubia-Gómez, P., Cornell, S. E., \& Fabres, J. (2018). Marine plastic pollution as a planetary boundary threat - The drifting piece in the sustainability puzzle. Marine Policy. https://doi.org/10.1016/j.marpol.2017.11.035

Wang, J., Tan, Z., Peng, J., Qiu, Q., and Li, M. (2016). The behaviors of microplastics in the marine environment. Mar. Environ. Res., 113, 7-17. https://doi.org/10.1016/j.marenvres.2015.10.014

Welle, F. (2011). Twenty years of PET bottle to bottle recycling - An overview. Resources, Conservation and Recycling. http://doi.org/10.1016/j.resconrec.2011.04.009

Winans, K., Kendall, A., \& Deng, H. (2017). The history and current applications of the circular economy concept. Renewable and Sustainable Energy Reviews. https://doi.org/10.1016/j.rser.2016.09.123 
World Economic Forum. (2017). The New Plastics Economy - Catalysing action. Available online: http://www3.weforum.org/docs/WEF_NEWPLASTICSECONOMY 2017.pdf

WRAP. (2016). Plastics Market Situation Report, http://bit.ly/103IH0N

Wu, C. S., Yang, Y. J., Fang, S. W., \& Chen, Y. (2012). Solution-processable and thermally cross-linkable fluorene-cored triple-triphenylamines with terminal vinyl groups to enhance electroluminescence of MEH-PPV: Synthesis, curing, and optoelectronic properties. Journal of Polymer Science, Part A: Polymer Chemistry.

https://doi.org/10.1002/pola.26184

Xanthos, D. and Walker, T.R. (2017). International policies to reduce plastic marine pollution from single-use plastics (plastic bags and microbeads): A review. Marine Pollution Bulletin, 118(1-2), 17-26

Yildirim, S., Röcker, B., Pettersen, M. K., Nilsen-Nygaard, J., Ayhan, Z., Rutkaite, R., ... Coma, V. (2018). Active Packaging Applications for Food. Comprehensive Reviews in Food Science and Food Safety. http://doi.org/10.1111/1541-4337.12322

Zheng, Y., Yanful, E. K., \& Bassi, A. S. (2005). A review of plastic waste biodegradation. Critical Reviews in Biotechnology. https://doi.org/10.1080/07388550500346359

\section{Useful links}

www.european-bioplastics.org/

archive.greenpeace.org/

www.wasteonline.org.uk/

www.packagingportal.com

https://www.ellenmacarthurfoundation.org/

https://www.icis.com/

https://www.plasticsconverters.eu/

https://eur-lex.europa.eu/homepage.html

https://www.plasticseurope.org/en 